Portland State University

PDXScholar

5-10-1974

\title{
Curanderismo and Health Delivery Services
}

Jean Margaret Blaesser

Portland State University

Follow this and additional works at: https://pdxscholar.library.pdx.edu/open_access_etds

Part of the Social Welfare Commons, and the Social Work Commons Let us know how access to this document benefits you.

\section{Recommended Citation}

Blaesser, Jean Margaret, "Curanderismo and Health Delivery Services" (1974). Dissertations and Theses. Paper 2046.

https://doi.org/10.15760/etd.2045

This Thesis is brought to you for free and open access. It has been accepted for inclusion in Dissertations and Theses by an authorized administrator of PDXScholar. Please contact us if we can make this document more accessible: pdxscholar@pdx.edu. 
AN ABSTRACT OF THE THESIS OF Jean Margaret Blaesser for the Master of Social Work presented May 10, 1974. Title: Curanderismo and Health Delivery Services APPROVED BY MEMBERS OF THE THESIS COMMITTEE:

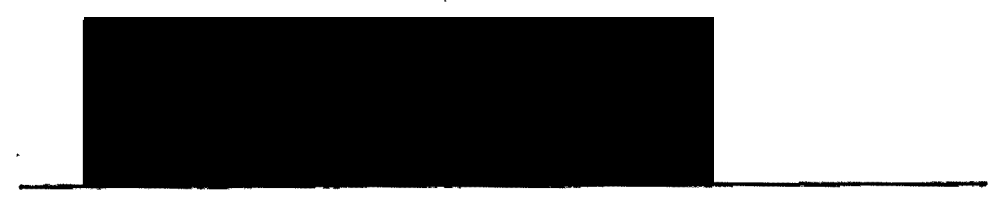
Arthur C. Emlen
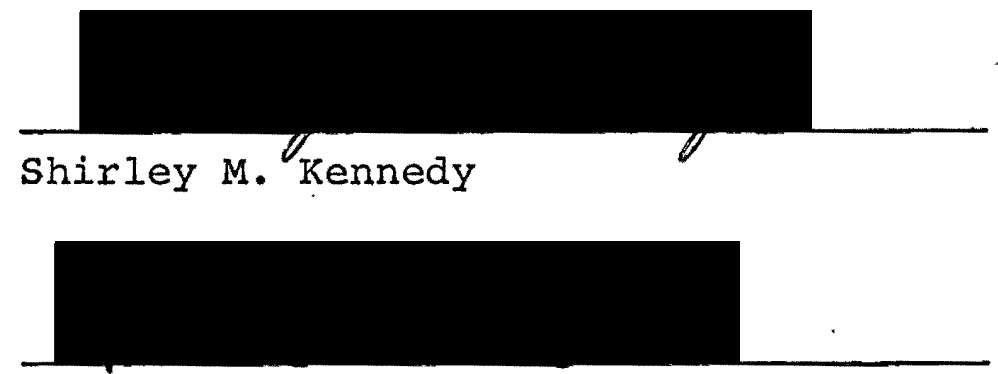

Lucia N. Peña

This study explores and describes curanderismo (folk curing) and the cultural disease concepts of mollera caida, empacho, mal de 0 jo, and susto as researched in a rural Oregon community. Chicano. cultural disease concepts and beliefs are then related to modern health delivery services, and a case is made for the need for cultural awareness, respect, and sensitivity on the part of medical personnel who deliver services. The approach of a curandera (curer) and a doctor are compared. 
It is strongly stated that Chicanos' health beliefs and practices do not exist in isolation from the rest of their culture, and that the concept of familia is a particularly important focal point in the harmony of this culture. It is suggested that health delivery services as well as all helping services cannot afford to neglect the totality of a Chicano cultural viewpoint if their services are to have relevance. Practical suggestions for health personnel are included. Data were collected primarily. through the participant-observer method. 


\title{
CURANDERISMO AND HEAITH DELIVERX SERVICES
}

\author{
by \\ JEAN MARGARET BLAESSER
}

A thesis submitted in partial fulfillment of the requirements for the degree of

MASTER OF SOCIAI WORK

Portland State University 1974 
TO THE OFFICE OF GRADUATE STUDIES:

The members of the committee approve the thesis of Jean Margaret Blaesser presented May 10, 1974.
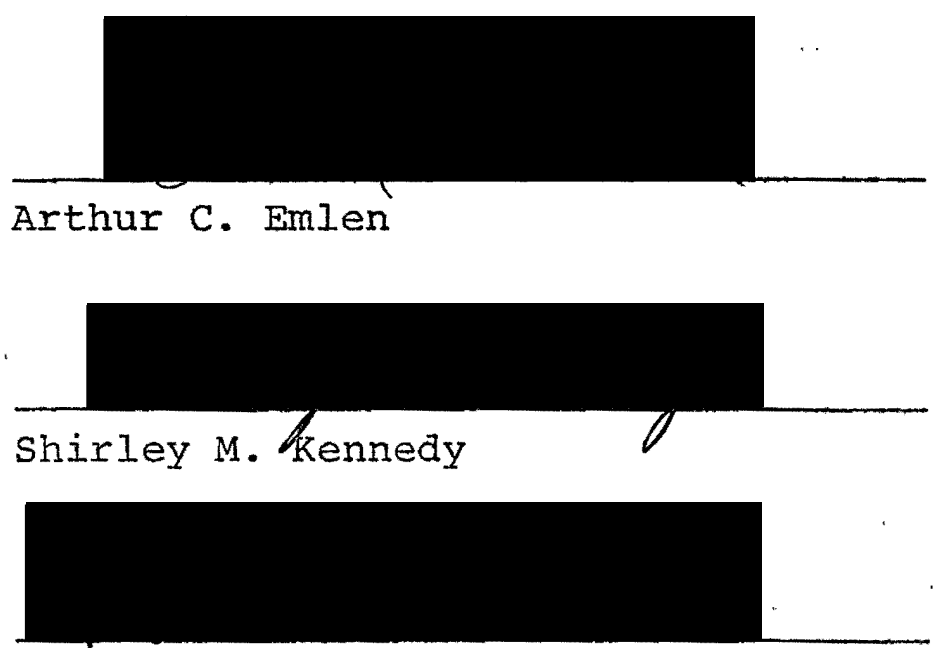

Lucia N. Peña

APPROVED :

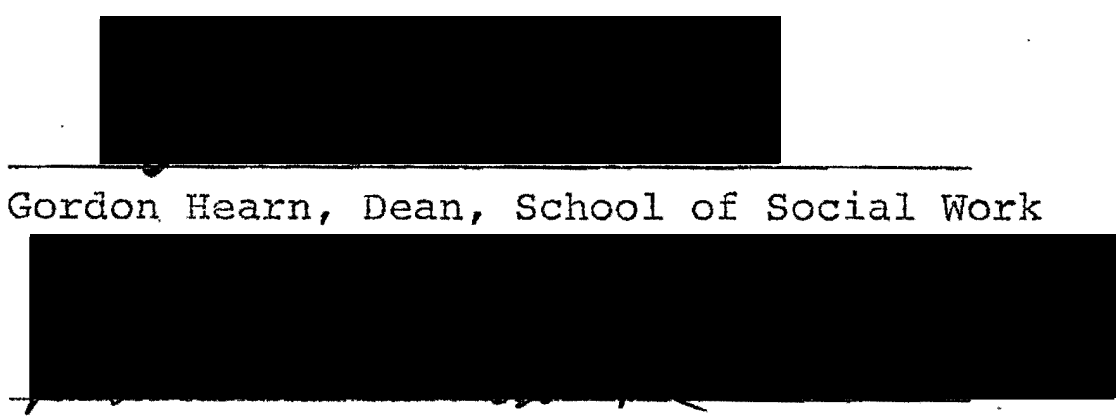

David T. Clark, Dean of Graduate Studies

May 10, 1974 


\section{ACKNOWLEDGEMENTS}

My special thanks go to the many Chicanas of the rural community who were willing to share theix culture with me and support this effort toward cross-cultural understanding.

The cooperation and mutual appreciation of Anglos and Chicanos made this study possible.

My appreciation is also extended to Lucia Pena, Shirley Kennedy and Art Emlen. 
TABLE OF CONTENTS

PAGE

ACKNOWLEDGEMENTS

\section{CHAPTER}

I INTRODUCTION .. . . . . . . . . . . . 1

II REVIEW OF THE IITERATURE . . . . . . . . 2

Curanderas (Curers) . . . . . . . 10

La Familia (The Family) . . . . . . 13

Cultural Disease Concepts . . . . . 16

Caida de la Mollera

Empacho

Mal de ojo

Susto

III STATEMENT OF PROBLEM . . . . . . . . . . 33

Rationale for Understanding

Curanderismo . . . . . . . . 33

Methods Statement: Chicano population and Data Gathering . . . . . . 36

Limitations of the study . . . . . . 44

IV FINDINGS . . . . . . . . . . . . . 47

View of Curanderismo in the Community . 47

Caida de la Mollera

Empacho

Mal de ojo

Susto

Miscellaneous

$V \quad$ IMPIICATIONS AND RECOMMENDATIONS • . . . 73 


\section{INTRODUCTION}

This thesis will concern itself with the relationship between adherence to folk medicine beliefs (curanderismo) and health delivery services. The purpose in examining such a relationship will be to suggest the importance of cross-cultural sensitivity, and the need for the health delivery services of the dominant culture to address themselves to the needs of the Mexican-American population. To this end, the belief system by which many Mexican-Americans explain disease will be discussed; the health care situation will be looked at; actual data gathered in a community will be discussed; and implications for health delivery services will be examined. This study will address itself not only to medical employees, but to the entire realm of personnel in the helping professions. 
II. REVIEW OF THE LITERATURE

Curanderismo is most beneficially approached with some background, part of which appears to touch on the Hippocratic concept of a balance between the body's hot and cold, and wet and dry qualities. Currier traced the origins back to a form of Greek humeral pathology and found that "illness is often attributed to imbalance between heat and cold in the body, and curing is likewise accomplished by the restoration of proper balance". (Currier, 1966, p. 251) Mexican-American folk medicine follows a line of thinking similar to that of classical humoral pathology. Currier's explanation for the persistance of the hot-cold syndrome long beyond that of the wetdry dichotomy involves the socialization process of the Mexican child, whom Currier felt was subjected to a period of intense rejection while going through the weaning process. What the child experienced in the process was translated into unconscious associations between acceptance, warmth, and intimacy on the one hand, and rejection, cold, or witharawal on the other.

In adult life these associations appear in those beliefs intimately concerned with the problem of personal security; theories about nourishment and about the prevention and cure of disease and injury. on a conscious level, then, the hot-cold syndrome is a basic principle of human physiology, and it functions 
as a logical system for dealing with the problems of disorder and disease. on a subconscious level, however, the hot-cold syndrome is a model of social relations. In this case, disease theory constitutes a symbolic system upon which social anxieties are projected, and it functions as a means of symbolicalily manipulating soolal relation cult and too dangerous to manipulate on a conscious level in the real social universe. (Currier, 1966, p. 252)

Currier gathered most of his data on Mexican folk medicine in Erongarícuaro, Michoacán during the summers of 1963 and 1964. From the time spent there, he felt that each individual in the Mexican peasant society needed to achieve a balance between the two opposing forces of the pull toward intimacy and that towards withdrawal. He proposed that such a fundamental pull in social relations was enacted through the preoccupation of achieving a balance between "heat" and "cold". Octavio Paz seems to relate to this when speaking of the anger and shame he feels the Mexican often experiences from having renounced his solitude and permitted an intimate exchange to occur. (Paz, 1961, p. 31)

The role the hot-cold syndrome plays in the balance of parts of the total person may be illustrated if qualities of foodstuffs are considered. As Currier points out, the historical roots of such a classification go back to medicinal and not culinary art. In addition, the temperature or calidad "of a foodstuff is relevant only to its effect on the human body, and then only because it might have an 
adverse effect on health". (Currier, 1966, p. 253) Qualities of hot and cold are also referred to in situations that do not have to do with food specifically, such as reluctance to expose one's warm body to cold night air. In Colombia, S.A., a similar phenomenon seems to occur when people cover their mouths and noses with handkexchiefs to protect themselves from the cold night air when leaving a warm theater. In addition, in the community in question, a practice was related that concerns the hot-cold phenomena. It was explained that women should take care of themselves for forty days following delivery of children because their pores are open, and air can get through. One must bind the stomach to keep the air out.

Returning to Currier, he states that "the only way of determining the calidad of a food or other substance is by observing the effect it has on an illness known to be hot or cold". (Currier, 1966, p. 253) Then too, there is considerable evidence from various researchers that agreement as to which foods are hot or cold varies from member to member within a community, community to community, and from one geographical area to another. Such evidence suggested that it was important that food be assigned a calidad, but that it made little difference which foodstuffs were classified as hot and which were known for their cold properties. In Erongarícuaro, some illnesses were explained by cold entexing the body; by an overabundance of heat within the body, or as caused by either 
heat or cold. Thus:

Cold

Chest cramp:

Earache:

Headache:

Paralysis:

Heat

Dysentery:

Sore eyes:

Postemilla:
Cold air enters the chest when a person is overheated.

A cold draft of air enters the ear canal.

The coolness of mist or of the night air, called aigre (a localism corrupted from Spanish aire, "air") penetrates the head.

A part of the body is "struck" by aigre. Stiffness, considered a partial, temporary paralysis, is ascribed to the same cause.

Stomach cramp: When the body is warm, and not adequately covered, cold can enter from the air or from a body of water.

Rheumatism: Cold from some outside source lodges in the afflicted bones.

Teething: The pain of teething is a "cold pain", originating in the coldness of the white new teeth that are growing in.

Tuberculosis: Cold enteres the body from water or carbonated beverages, especially when the body is overheated from work or travel.

Since it is accompanied by bloody stool, and since blood is intensely hot, dysentery is classed as a hot disease, and may be caused by consuming too much hot food.

A person may overstrain his eyes, causing them to "work hard" and thus to heat up, or alternatively, cold wet feet can cause the body heat to rise to the head, overheating the eyes.

Kidney ailments: Any pain in the kidney is a hot pain; most kidney ailments are accompanied by itching feet or ankles, a reddening of the palms of the hands, and fever. An abcessed tooth results from heat concentrating in the root of the tooth, evidenced by the fact that when the abcess bursts it releases blood. 
Sore throat: Wet feet cause sore throat by driving the body heat up into the throat. warts and rashes: Whatever their cause (a subject upon which my informants refused to speculate), these ailments are the result of heat. This is a conclusion from the fact that warts and rashes are ixritating, and irritation is always ascribed to heat and never to cold.

Heat or cold

Diarrhea:

Enteritis:

Diarrhea is usually cold -- caused by "cold in. the stomach" -- but it may also be hot. In the former case the feces are merely loose; in the latter they are green, and steam when fresh. A case of diarrhea, if not checked, may develop into a case of torzon or enteritis, a more serious ailment. Torzon may be of either the hot or cold variety, and these types are again distinguished by the appearance of the feces - hot if these are streaked with blood, cold if they are white and covered with mucous (the cold-wet humor of classical theory).

Toothache: Pains in the molar teeth are hot, caused by improper diet. Those in other teeth are usually cold, in which case they are allegedly caused by a draft of air. (Currier, 1966, pp. 253-4)

It may be helpful to briefly discuss the rationale behind possible contraction of diseases caused by cold, heat, or both. Illness deemed a result of cold is usually caused by an intrusion of an amount of colaness into a part of the body; the body is considered particularly vulnerable to such intrusion when it is unusually warm, from whatever the activity. When referring to illnesses caused by excessive heat, the phenomenon in question is that of heat 
most often generated from within the body itself. Currier points out that while heat in the external world is fairly predictable, heat within the body has the dangerous potential of being aisplaced or relocated upwards in the body. The stomach is the accepted location of most heat in the body, while one's extremities should be relatively cool. However, were the feet and legs to be in contact for too long a period with cold ground or wetness, the normal body heat within them would withdraw and move upward into the throat and head, endangering the eyes and mouth. And finally, those disorders caused by cold or heat encompass almost entirely digestive problems. This would follow from the notion of achieving a good balance of hot and cold foods, and implies that an excess of either could be harmful. Both hot and cold foods need to be injested to achieve a good balance and to keep the body in good health. (Currier, 1966, p. 255) In summary then, Currier states that:

While sensations of pain are usually cold, sensations of irritation are hot. All skin ailments I know of are caused by excess heat on the surfaces of the body. It is thus a general principle of this system of pathology that cold harms the individual by invading his body from without, while heat harms the individual by expanding (or being displaced) from the center of the body outward to its surfaces. Finally, hot illnesses are not only visible but conspicuous to the outside world, taking the form of skin eruptions, fever, coatings, and hoarseness. Cold illnesses, on the other hand, are often not at all visible to the outside world; their principal symptoms are pain and immobility. (Currier, 1966, p. 255) 
Consideration of the proper balance of hot and cold as it relates to food and everyday activities are also recognized by Rubel when defining a healthy individual as one whose entire being is in balance. If an individual is perceived as a sum of balanced parts, then four males naturales (natural diseases), caída de la mollera, empacho, mal de ojo, and susto, can be looked at as an imbalance of parts.or qualities of the healthy individual.

In Mexiquito, Texas, Rubel found that males naturales are considered to be within the realm of God whereas the category of mal puesto or mal artificial (unnatural illness) refers to the realm of the devil (Rubel, 1966, p. 156) and may include brujos (witches). Skepticism regarding witchcraft may now be widespread although it should be remembered that chicanos do not necessarily compartmentalize the natural versus the supernatural as do Anglos. This is not to say that Chicanos do not recognize the germ theory of illness or the usefulness of medication, but that many recognize other sources of illness.

Mexican-American folk medicine classifies disease mainly according to cause rather than symptoms. The primary classification of disease distinguishes two major categories: 1) the so-called "good" or "natural" illnesses, which come from violating the balance of the natural world controlled by God; and 2) bewitchments sent by human adversaries utilizing evil Satanic forces. A natural illness is corrected by restoring the particular balance that was disrupted. Bewitchment is cured by countermagic or by removing the immediate source of harm. (Madsen, 1964, pp. 71-2) 
Briefly, illness may be viewed as a part of life to be borne with the same sort of courage and dignity with which one faces fear, sorrow, hunger, death and pain. An effort is made to continue regular activities and responsibilities as long as one is able; one does not give in to illness with the first appearance of symptoms. Children are not usually expected to face illness with the same stoicism as their parents. Clark mentions that while in Anglo groups one often hears remarks that express a sense of guilt on the part of the sick person, in Sal si Puedes the sick person was generally not held responsible for becoming ill.

...the patient is regarded as a passive and innocent victim of malevolent forces in his environment. These forces may be witches, evil spirits, the consequences of poverty, or virulent bacteria which invade his body. The scapegoat may be a visiting social worker who unwittingly "cast the evil eye". It may be a member of the sick man's social group who "made him sick" by frightening him, making him angry, or otherwise upsetting him emotionally. Blame may be projected to the demands of life in urban America. (Clark, 1959, p. 197)

Kiev found that an individual's good health implied the existence of a good balance with God and with the customs of the people. These customs focused around the family, the church, and one's fellow man. As the more traditional patterns of behavior in the Mexican-American community are somewhat shaken, as they are by changing child rearing techniques, changing role of women, and the breakdown 
of the traditional family, an individual is more prone to the development of conflicts, bad habits and trouble. Immigration and urban living are seen as influencing these patterns of behavior. (Kiev, 1968, p. 37) Good health leads to a discussion of curanderas.

\section{Curanderas}

Saunders relates some useful information for the understanding of folk curing and curanderas:

Folk medicine differs from scientific medicine in a number of ways. In any culture, it is generally the common possession of the group. In a folk culture, there is relatively little division of knowledge with respect to medicine, so that what one adult knows about illness and its treatment is usually known by all other adults. Although knowledge of the origins of folk medical practices and beliefs may have largely been lost, the practices and beliefs themselves are often so rooted in tradition that they seem a part of the natural order of things and are as much taken for granted as is the daily rising and setting of the sun. Folk medical lore is transmitted from person to person and generation to generation by informal methods... One learns it, much as he learns other elements of his culture, as an incidental part of his everyday associations. Folk medicine is usually well-integrated with other elements of a folk culture and is reinforced by them. (Saunders, 1954, p. 145)

As specialists in the diagnosis and treatment of folk diseases, curanderas (feminine gender) and curanderos (masculine gender) appear to be an integral part of folk curing. They are not professionals in the sense of having received formal training in the practice of medicine; nor do they usually earn a living through their practice. As community members who have learned more of their culture's 
medical lore than other barrio (neighborhood) members, they are regarded as specialists. (Clark, 1959, p. 207)

If a Chicano is afflicted with an illness, he or she may treat themselves, request help from their mother, seek 1 out a friend, compadre (god parent) or relative who has knowledge of herbs and treatment, or go to a curandera. Such a process can be seen as a lay referral system and fits well into the theory of natural systems.

Collins speaks of the natural neighbor when discussing the natural system of service delivery and day care providers. A natural neighbor can also be seen as a curandera, an integral part of a health delivery system.

The natural neighbor must be seen and accepted in the same light as the more conventional educational or medical professional. It is true that he does not himself openly equate his activity with teaching or nursing, and that the general public is even less aware of his functioning. But objective consideration discloses that each natural neighbor is an expert in his own field and while he is self taught has a body of knowledge that he can bring to bear on individual situations; that he is constantly seeking to increase his usefulness and skills; and that he has an interest and willingness to invest time and energy on behalf of those he serves that may exceed that of more conventional professionals. (Collins, 1972, p. 2)

In his study in San Antonio, Texas, Kiev found that most curanderos learn their skills through apprenticeship to an older curandero, and that such knowledge is not acquired in a state of isolation or subjection to ordeals. Nor do curanderos become possessed. Their healing powers come from God, and abuse of their healing ability only leads 
to its loss. Curanderas and women with knowledge of curing are not regarded as having supernatural powers and the people do not treat them with awe; few curanderas are overwhelmed with their own healing powers. A curandera's home might contain various religious objects such as crosses and pictures of saints, and perhaps an altar. Curanderas might charge a small fee, or they may be reluctant to do so; donations or offerings are accepted. Curanderas may use their own personalities to arouse expectation of help in their patients, and Kiev believed that a personal forcefulness like this was made possible by the healer's close adherence to both the religious beliefs and the norms of the group. (Kiev, 1968, p. 31) For actual curing, a curandera would most likely make use of herbs and purgatives, employ massage with the use of herbal mixtures and/ or oil, regulate the diet, and engage in informal counseling. A further note on curanderas, and a very important one, concerns the relationship with the patient and family. Madsen notes that such a relationship is best characterized as warm and intimate, with the patient treated both as an individual and as a member of a family unit.

...illness is always a matter of family concern. The curandero shares his diagnosis with the family and carefully explains each step of the treatment. It is customary for at least one member of the family to accompany the patient to the curer's home, and family members are often asked to aid the curer in administering the treatment. Throughout the period of treatment, a very close and affective relationship is maintained 
between the curer, the patient, and the patient's family. Never does the curer say he is too busy to sit down and discuss the ailment with the patient and his family. The curandero openly suffers with the patient when he experiences pain and rejoices with him when the signs of recovery appear. (Madsen, 1964, p. 91)

La Familia

Because of the importance of the family in the treatment process of sick individuals, it is appropriate to look at the overall value and importance of the family to the Chicano. While speaking of cultural traits or values, it should be remembered that there is no cut and dried way Chicano families would behave; at the most, one can say that there is a greater Iikelihood that a Chicano family would behave in accordance with a particular value than would an Anglo family.

For the Chicano, the family is likely to be the single most important social unit in life. It is usually at the core of his thinking and behavior and is the center from which his view of the rest of the world extends. Even with respect to identification the Chicano self is likely to take second place after the family. For example, an individual is seen first as a member of the Ruiz or Mendoza family before he is seen as Manuel or María--that is, before he obtains his more personal acceptance. Thus to a significant extent, the individual Chicano may view himself much of the time as an agent or representative of his family. (Muril1o, 1971, p. 102)

The family is able to maintain this position by providing emotional and material comfort, and a feeling of importance as a family membex is developed from an early age. Significant in the family is that much of an 
individual's self-esteem is related to how he perceives and how others perceive him carrying out his assigned family responsibilities. Values may be more clearly defined, and there is perhaps less deviance from an accepted sexual role than is common in Anglo culture. There is usually less sibling rivalry in the Chicano family, perhaps due to the status each child is awarded from age, sex, and family obligation. Children are expected to share, cooperate and work togethex for the good of the family. (Murillo, 1971, p. 104) In addition, in a wider world often hostile to those not of the dominant culture, the family can serve as a welcome support and refuge for weary individuals.

Both Madsen and Rubel agree with the importance of the family as a focus of social identification, and Rubel spends considerable time on the extended family and kinship terminology. Rubel found that an individual's basic social unit was made up of his parents and his parent's brothers and sisters, of whom his mother's sisters held particular importance. The grandparents are revered, but the grandparents' siblings do not necessarily share this special regard. An individual's own siblings are very important to him, as are his first cousins (primos hermanos) in particular. (Rubel, 1966, pp. 55-6) A system of godparentage or compadrazgo expands the network, and perhaps the most important members are compadres or godparents. Compadres hold a special relationship to both the parents 
of the child and the child they sponsor. In a sense, compadrazgo is a way of formalizing informal friendship ties. (Clark, 1959, p. 158) For example, friends as well as relatives fyequently become sponsors of children, and in this way existing relationships are reinforced. Women in particular, it seems, have close relationships with other women in their family or compadre networks, perhaps because their contacts with the outside world are traditionally more restricted than those of Chicano men.

A recent study of the Chicano family in Los Angeles and San Antonio concluded that there was "a substantial departure in the contemporary family from the traditional patriarchy. The departure is greatest among the young, the more well-to-do and those living outside the Mexican colony". (Grebler, Moore, and Guzmán, 1973, p. 320) The authors suggest that "in some respects the internal structure of family relationships has been reordered as MexicanAmericans have moved more fully into the urban midale-class situation and culture. The family may be no less important now than in the past, but the importance and elaboration of, for example, a woman's relationship to her sister may have declined as the importance of her relationship to her husband became enhanced." (Grebler, Moore, and Guzmán, 1973, p. 327)

Returning to the significance of the family as regards health delivery services and an indiviaüal's treat- 
ment, Clark makes a significant statement: After covering education, economic level and religious beliefs as factors affecting medical attitudes, she states:

None of these (the above), however, exexts a more powerful influence on individual health practices than do the customs which prevail in the homes of Spanishspeaking people. Among Sal si puedes families there are beliefs and customs regarding pregnancy, childbirth, and infant care which directly influence maternal and child health practices. Customs and beliefs concerning food affect nutrition. The pattern of family authority may determine when an individual is free to seek and receive medical aid. Attitudes toward the aged are involved in determining whether or not an elderly person suffering from serious chronic disease will be hospitalized. The individual's relations to his family and kinship group influence his personal adjustment and mental health. (Clark, 1959, p. 118)

Good medical care for the Spanish-American culture may require that the patient be treated for many conditions at his or her home, and by relatives and friends who are constantly in attendance to provide emotional support as well as the needed skills for treatment of an illness. An individual would expect his family to support and surround him in time of sickness, and to supervise closely and critically if not actually participate in the treatment process. Family members likewise feel obligated to stay close to the patient, perhaps take charge of his treatment, and reassure him of his importance to the family. (Saunders, 1954, p. 166) Although the extent to which family involvement is depicted above may not be the case in the Chicano community today, even partial involvement coula run counter 
to the usual mode and manner of Anglo health delivery services. This difficulty will be more fully addressed in chapter five,

Caláa de la Mollera

In the following pages, beginning with the concept of calda de la mollera, or "fallen fontanel", an effort will be made to describe each manifestation of illness while relating it to possible belief systems and research done by others.

Caída de la moliera affects young children only since the ailment concerns the soft spots covered by membrane on the top of a baby's head. The back fontanel closes first, and the front closes at around one and a half years of age; it appears that the fontanel in question is the front one on the baby's skull. Rubel explains mollera calda in a way he feels related to a Spanish-speaker's belief that infants have a fragile skull formation. In his understanding, the mollera (fontanel) is that part of the skull pictured as sitting at the very top of the head, sustained in the correct position by the counteracting pressure of the upper palate. A fall from a height with a subsequent blow to the head would be sufficient to dislodge the fontanel, causing it to sink, and in turn depressing the upper palate. The latter would result in blockage of the oral passage. If an infant fell from a chair or bed, the mother or another adult present would immediately examine the infant's skull in search of a 
depression. If found, treatment would begin in order to correct the relationship of the parts to the whole. (Rubel, 1966, p. 797)

If no one witnesses the fall, the condition is often diagnosed by an infant's failure to grasp the nipple firmly with his mouth while trying to suck, as well as by the presence of diarrhea, crying, restlessness, and quite often a high temperature. In Sal si Puedes, Clark found that in addition to observing the fontanel for depression, a further diagnostic procedure was to feel for a bolita (little ball) in the roof of the child's mouth. The bolita, if found, affected the correct closure of the baby's mouth, and although the child tried to suck, it could not get enough to eat. (Clark, 1959, p. 171)

Since the relationship of one of the parts of the body is out of balance with the whole, all treatment, however varied from region to region, involves returning the soft spot to its proper location. In Mecca, Rubel found that because of the delicacy of the procedure, many of the younger women would take their child to a curer, who held the child in her arms, face up. While reciting the prayers Crédo Catblico (Catholic Creed), Ava Maria, and Padre Nuestro (Our Father), the healex places a thumb against the upper palate of the child, and pushes upward three times. At the same time, an external pull is applied, usuaily by pulling the hair lightly three times, or by filling the 
mouth with water and sucking (chupax) at the depression. Were the case to be a grave one, the contents of an egg would be rubbed into the child's hair above the depression, and no other external pulis would be necessary. After attempts to push and pull the fallen parts back into correct position, the curing process is usually terminated by holding the child upside down by the ankles and shaking him three times in a brusque manner. An alternative is to turn the child on his side in the arms of the curer, and then brusquely shake the body toward the head. The entire process ends by lightly tapping the child's feet three times. It is important to treat caída de la mollera promptly and correctly since blocking the oral passage prevents proper digestion of foods and will eventually cause an infant to dry out. (Rubel; 1966, p. 798)

clark felt that "the concept of mollera seems to be based on the observed loss of subcutaneous fluid over the fontanels -- a result of dehydration caused by infant diarrhea. There is a confusion of cause and effect in folk belief; the depressed fontanelle and the exaggeration of palatal rugae resulting from fluid loss are assumed to be primary causative factors. (Clark, 1959, p. 171)

Kiev approached calda de la mollera from a different angle, and saw the phenomenon as a means to explain a child's problem in a culturally meaningful way -- one that also took attention away from the mother and any possible role 
she might have had in the child being sick or harmed through inattention or neglect.

Proper mothering is the focus of much anxiety, activity, and watchfulness on the part of others. This area is of special importance in this traditional culture where the weight of child training and education for adjustment centers almost exclusively on the home, and where great emphasis is placed on the conformity of the child to clearly defined age and sex roles. That the status of the parents, especially the mother, is very much tied up with the child, makes the parents somewhat dependent on their own children for the security and respect they obtain in this social system. (Kiev, 1968, p. 106)

\section{Empacho}

Empacho affects both children and adults, but is more commonly seen in children. It is perhaps best conceived of in an anglo frame of reference as a form of indigestion, and is said to occur when undigested food fails to pass through the intestinal tract. This chunk of undigested food may form a ball that sticks to the wall of the stomach or intestine, and often causes pain. Clark found empacho to be characterized by the presence of a large ball in the stomach which produced swelling of the abdomen. In her study children under two years of age were thought to be particularly prone to empacho. One neighbor told her: "You can tell when a baby has empacho because it will keep on trying to eat, but will vomit its food as fast as it eats. It also gets colic and cries a lot and may haye a little diarrhea and fever. You can diagnose it by feeling the calves of the legs for little bundles or knots along the 
nerves." (Clark, 1959, p. 179. Clark also seemed to find a connection between the hot-cold theory and empacho. Her informants believed that overeating of cextain foods, especially cheese and eggs (for infants onlyl, and bananas, as well as too much soft bread (rolls, biscuits). could cause empacho. (Clark, 1959, p. 179)

Madsen found that people in south Texas thought empacho could be caused by a severe emotional disturbance or by eating too much of heavy foods such as bananas, rice, or potatoes, which could get stuck in the stomach. The treatment for empacho consisted of:

...removing the ball of foodstuff through the use of purgative herbs and massage. The treatment for children involves rubbing the stomach and back with oil in a downward manipulation designed to help the food pass out of the body. The skin on the lower part of the back is pinched and pulled at the sides in order to straighten out twisted muscles blocking passage of the food. The dried herb called hoja sen (Cassia diphylla, Legumunosae) is mixed with cotton thread, burned to ashes, and mixed with milk that is fed to the child to break up the ball of food. After the child has passed the food, his upset stomach is soothed by an infusion of istafiate boiled with milk. Because the treatment makes the child weak, he must be kept warm afterward. (Madsen, 1964, p. 75)

One Mexican-American mother Kiev spoke to described the cure for empacho in this manner:

To treat it, you rub their stomach real good and rub them with an egg at room temperature, not from the fridge, and then you rub their stomach real good with it. Wherever that egg bursts, that is where the empacho is in the stomach. Then they tie a piece of linen around to hold it there. After they a all the 
rubbing and applying of the egg, they give them a good dose of castor oil or sometining to make them move their bowels. Some kids seem to get empacho over and over again. They get it real easy. It doesn't happen to the kids whose parents worxy about. What they eat; it seems to happen to the kids whose parents don't care what they eat. (Kiev, 1968, p. 134).

Empacho can be differentiated from other intestinal trouble by pinching the skin along the lower back and listening for a crack or snap that comes from the abdominal region.

Rubel found that people of ten suspect that an individual was required to eat against his will when said individual has an empachado condition. An example mentioned to Rubel concerned parents calling a son away from his play in order to come to the dinner table. The difficulty the youngster has in stopping his play to go eat is considered reason enough to cause the child to have empacho. Also operating here are conflicting cultural values. For example, while obeying his parents was the proper way to show respect, such an act also conflicted with the ideal behavior of the independent male. Another example given was the situation of a visiting guest who is invited to eat when he has just eaten or is not hungry. Refusal of such an invitation would be insulting to the host, and yet the guest may well have wished to refuse the invitation on a full stomach. (Rubel, 1966 , p. 800). 
Mal De ojo

The third of the males naturales is mal de ojo and Rubel's findings are interesting in this regard. He felt that for the Mexican-Americans of Mecca, social relationships were thought of as bearing inherent dangers to the balance of the individual. While all individuals were regarded as potentially susceptible to mal de ojo, the "weaker nature" of women and children made them somewhat more receptive than mature males. The locus of the power that certain stronger individuals have over weaker individuals is in the eyes, and Rubel found that the classic cause of mal de ojo in Mecca was one that contained elements of covetousness. However, cause is generalized to include any kind of special attention, for strong glances, covetous expressions or excessive attention paid an individual may expose those involved to the dangers of an unnatural bond. Physical symptoms appear suddenly and are severe headaches, inconsolable weeping in the case of children only, unusual fretfulness and a high temperature. A careful person will recognize the appearance of pain on his or her temples as associated with having coveted someone, usually a child, and will attempt to prevent any further problems by rupturing the bond between himself and the other. At this stage, the bond may be broken by passing a hand over the forehead of a child, or by patting it around the temples. 
It is sometimes difficult to locate the unsuspecting agent of mal de ojo, as for example, when a family goes downtown to shop and comes into contact with a great many strangers who may admire the child from a distance and not touch him. If the person with the strong glance is known however, or can be recalled, he or she is contacted and asked to rupture the bond so that the intrusive power of the agent is eliminated from the other. Rubel found no instance of refusal. (Rubel, 1966, p. 800-I).

Indeed, people. who possess "strong vision" are considered guiltless since they were simply born with strange power in the eyes. This force is unconsciously projected by the possessor and may affect people, animals or objects that are admired: Madsen felt mal de ojo to be to some extent a reflection of envy although this was not mentioned to him by informants. Children are considered especially vulnerable to mal de ojo because they do not yet possess the spiritual and physical strength of adults. Although easily cured in the early stage, mal de ojo can cause serious problems if left untreated, and symptoms range from nervousness to rashes, sores, aches and pains. Children manifest insomnia, trembling, and intense crying, with or without fever. (Madsen, 1964, pp. 75-6).

Kiev encountered a curandero who described mal de ojo as follows: 
Fever and throwing up and real sleepy are the symptoms; like they have tonsillitis or sore throat or something. Only they don't realiy have tonsillitis. They don't want to eat. They throw up, especially milk or eggs. They have to get something cool in their stomach, something to slow it up. They create so much fever in their stomach that if they arink milk it will curale. The evil eye is caused by somebody ordinary, like you or I, looking at the child and wanting to touch the child but not touching the child. The electricity of the person is sent off to the child. Some people have more than others. If the child is little it can't overcome this electricity until you cure it. (Kiev, 1968, p. 103).

Rubel found the following cure for mal de ojo:

A hen's egg is taken and rubbed whole over the patient's body to absorb some of the heat and power which has disturbed the balance of the youngster. A water glass half full of liquid is brought close to the sufferer and the egg is tapped three times on the edge of the glass. On the third blow the shell is broken open, symbolizing the rupture of the bond between the patient and the stronger individual. The egg is emptied into the water glass where it is permitted to settle and assume a diagnostic form. If the form assumed by the egg in the glass suggests a "cooked" shape, i.e., sunny-side-up, the condition is diagnosed as one of mal ojo. An elongated shape bespeaks a male cause, a round shape a woman agent. Whatever the result of the diagnosis, all patients who have had the preliminary stages of the treatment (the combined forces of the calm rubbing of the whole egg on and about the body and the quietness of prayer and conversation in a therapeutic atmosphere of tenderness and concern, usually with one's most warm relative--the mother or grandmother) reports a suffusing relaxation of body and mind. (Rubel, 1966, p. 801).

A sequential treatment would follow were the diagnosis to point to mal de ojo. The purpose of the subsequent treatment is to drain the intrusive power of the stronger individual from the patient, and this can be accomplished by placing the water containing the egg beneath the head of the 
patient's bed, Left throughout the night, by morning the draining powers of the egg are said to have drawn the alien power from the subject's oxganism, The water and egg should then be removed from beneath the head of the bed, and disposed of by burying the mixture in the yard, or flushing it in a commode. Because the egg and water now contain some essential properties of both the actors in the bond, they must not be subjected to the sun's rays on a garbage pile, nor to scavenging animals--to do so would result in drying up the eyesight of the agent and the patient. (Rubel, 1966, p. 801) Clark mentioned diarrhea and vomiting in addition to those symptoms indicated by Rubel, and considered mal de ojo to have a magical origin. In Sal se Puedes, it was believed that if someone, especially a woman, admired another's child, and looked at him without actually touching him, the child could become ill with mal de ojo. Again, anyone can cause mal de ojo, and the offending person may not even be aware of the damage done. One prevents the affliction by touching the child after admiring it, or before taking one's leave. (Clark, 1959, p. 172)

Were mal de ojo to go untreated, or be treated incorrectly by doctors, it could proceed to a stage called ojo pasado which is often fatal. Rubel found severe vomiting and coughing characteristic of ojo pasado, the danger being that their violence can cause the bile sac (hijel) to break, releasing green bile and causing death. 
Commenting on mal de ojo, Kiev found that courtesy, formality, and respect toward parents was also extended to relationships with others, and that the ideal man and woman in San Antonio exerted quite a bit of self-control. He related this idealized pattern of non-involvement to the evil eye and to the reinforcement such a pattern receives from the concept of mal de ojo. Emotions are potentially dangerous, seem to have a power of their own, and need to be guarded against. Just as smiling at a pretty child could bring about mal de ojo, many folk illnesses exhibit the components of loss of self-control and excessive emotionality. (Kiev, 1968, p. 58).

Kiev adds a historical perspective to fear and of the evil eye when he notes that the fear is found among people in many parts of the world, and there exist descriptions of it dating back to antiquity. He feels that the fear is expressed as mal de ojo among Mexican-Americans, and agrees with clark that it often strikes a child to whom affectionate overtures have been made without physical contact. Ojo relates to care of the child as do both empacho and calda de la mollera, but brings into consideration other individuals outside the family group.

This relationship appears to be not only a projective maneuver but also a form of recognition of the fact that other individuals outside the family circle have upset the rather rigid and formalized arrangements of family activity. Thus, in mal ojo we find parental anxiety and guilt being projected onto a stranger -- 
pexhaps one who has disrupted the customary routine of the household or has acted in a way to upset the normal balance of interpersonal relationships. (Kiev, 1968 , p. 107).

Susto

The last mal natuxal in question is susto (fright), usually seen as a result of a natural fright, and usually separated from a condition called espánto (bad scare). However, Madsen found that while a curandera separated the two diseases on the basis of the part afflicted (frightened heart vs. Erightened spirit in espánto), the average Mexican-American lumped the two together as one affliction, with preference for the term susto. One of Madsen's MexicanAmerican informants made the following comment: "Fright is a real disease recognized by doctors who call it by another name. Just because we call it susto or espánto, the Anglos mock it as superstition. Anyone who has been frightened may become ill. Call it 'shock' or 'nerves' like the Anglos and people will say you are scientific." (Madsen, 1964, pp. 77-8).

An example of fright as given by Madsen was that of pedro who managed to escape to safety after being chased by an enraged bull dog. Although unharmed, he developed fright sickness. Madsen notes that emotional arguments and selfpity can cause fxight illness and that symptoms are exhaustion, restlessness, and loss of appetite. A person might lose interest in doing anything and may refuse to eat; 
family members observing such symptoms urge the sick one to try to remember any frightening experience that may have brought on the illness. If the affected one is able to recall such a recent experience, the diagnosis of fright sickness is confirmed. At times curanderos determine fright sickness by taking the pulse, which is said to be irregular, and slow down and then speed up again. Advanced fright sickness is known as susto pasado and the services of a curandero are absolutely essential in these cases whose symptoms are prolonged exhaustion and coughing or fits. Madsen states that cases of susto pasado are sometimes diagnosed as tuberculosis or as epilepsy when physicians are consulted. (Madsen, 1964, p. 78).

In Mecca, Texas, Rubel found that a person who suffers from listlessness, lack of interest in ongoings, and lack of appetite is presumed asustado. The experience that resulted in susto may be of a frightening nature such as a fall from a horse, a fall caused by tripping over an unnoticed object in one's path, or a dog barking unexpectedly when close at hand--it may also be an individual's patterned reaction to the problems of everyday social life. A part of the self, the espiritu (spirit) is said to leave the body in susto, and the most common cause is the impingement of society upon the individual. In addition, social situations which might arouse anger or fear in the individual are avoided lest they possibly cause one's spirit to wander. Rubel relates 
an experience of the Montalvo family who:

.... went to a nearby lake for a picnic one sunday in April. It was young Ricardo's first experience in a' body of water and though coaxed and entreated by his family to venture into the water, he refused and remained an anxious onlooker. As the family continued to frolic outdoors, five year old Ricardo went to the car and fell asleep in the heat of the noon. He slept long and heavily throughout the afternoon and was carried, still slumbering, to his bed when the family arrived at home after dark. Several times during the night Ricardo was fitful and talked aloud in his sleep. The next morning the family assumed that he had been asustado the previous day, although not out of fear of the water.. Rather, it was the family's insistence that he enter the water, demands to which he could not accede, the father explained, which was causing the syndrome of susto. The day following the outing saw Ricardo brought to a neighboring woman to be cured. (Rubel, 1966, p. 805)

In susto as in mal de ojo, an essential part of the self is lost or overcome by a stronger alien force; the result is detrimental to an individual's equilibrium. Treatment procedures once again attempt to restore the loss of balance as it is manifested by somatic illness.

The patient is made to lie down with arms outstretched so as to resemble a cross. ...The patient's body is swept with a branch of the herb pirúl. The sweeping commences from the chest and stomach proceeding in lateral directions, and also upwards and downwards toward the extremeties. Before sweeping, however, the curer and patient talk over matters of a personal nature such as might throw some light on the reason for the condition. As the cure progresses with the sweeping motions, the curer prays in calm quiet tones, and the patient hopefully calls out to his wandering espiritu to return. Sometime during the calm-enveloped treatment a sudden sputter of liquid, either water or liquor, is emitted from the mouth of the healer, shocking the patient and bathing him about the face. Both patient and curer 
recognize when the treatment has succeeded in reuniting the wandering espiritu with the body. The patient for his part "feels" that his espiritu has rejoined his body; he begins to feel whole once again, ..... The curer realizes the passing of the critical period when a drop in body temperature and a lessening of fitfulness is ascertained. A treatment may last for three days in more serious cases of susto pasado.' At the conclusion of the treatment, the patient is instructed to drink the water from a special receptacle in which are floating herbs and palm leaves blessed during Easter services. (Rubel, 1966, p. 804 l.

Clark's data around susto appears to relate primarily to children, and at times, pregnant women. Since the unborn child will be born with susto if a pregnant woman is asustada (frightened), the future mother should take care to eliminate the potential threat and take a glass of warm water, drop a few live coals from the fire into it, add a little sugar, and drink it right away. Alicia informed clark:

Susto is a very bad thing to get--you can die from it. Children mostly have it. Something scares them real bad, and it seems like they just can't stop being scared from then on. When a child has susto, you can tell because he is very pale and thin and doesn't want to eat. He gets big round eyes and look sad, and he always has headaches. He shakes and trembles and is scared of the least little thing. (Clark, 1959, p. $176-7)$.

A common cure for susto in California was as follows:

Cut two branches of leaves of a sweet-pepper tree. Take a candle and mount it in the middle of a saucer on the floor. The child should walk across it (legs apart, one foot on each side of the saucerl in one direction, then across it again at right angles, making a cross. Then take the branches of pepper leaves and 'sweep' the child with them all over, first 
from top to bottom, then across from left to right, making the sign of the cross. Go on with the sweeping until you have finished reciting three credos (Apostles' Creed). After this, put the child to bed with the two pepper branches laid to form a cross under the child's bed. Just as you walk away from the bed, you must call out three times: 'Vente (child's name), no te quieres ni te espantes (Come;. you don't need anything and you aren't afraid. ${ }^{\top}$ When this sentence has been recited three times, the cure is over for that night. The cure should be started on a Wednesday night just before bedtime, and must be repeated in its entirety the following two nights,... at the same hour. After the third night's treatment, it is thought that the child is cured of susto if he can be cured at all. (Clark, 1959, p. 177)

From a psychoanalytic viewpoint, Kiev sees susto as a form of phobic anxiety and depression, usually shown by symptoms of depression, anxiety, and withdrawal from one's usual social activity and responsibility. He agrees that it is believed due to a sudden fright which leads to the soul's escape from the body, and feels that susto is more likely an explanation evoked after an individual has fallen ill. In this context then, Kiev regards susto as a culturally meaningful anxiety hysteria syndrome that permits the sick to be recognized. In addition, Kiev saw susto as occurring more often as a result of personal experiences with which people were unable to cope, than as a result of direct interpersonal experiences. It seemed to occur most often after the death of a loved one or after a frightening experience. (Kiev, 1968, pp. 118, 170) 


\section{STATEMENT OF PROBLEM}

The rationale for examining curanderismo (folk-curing) and its relation to health delivery services may be illustrated by briefly looking at mental health services in relation to Chicanos. A WICHE/NIMH task force came to the conclusion that in general, mental health services have always been irrelevant to Chicanos, and that the major factors blamed for lack of use of facilities were in the language factor, the high fees, and the location and appearance of facilities. Members of the task force felt that until recently, no one had looked at the relevancy of the methods of diagnosis or those of treatment -- both decidedly based on the use of the medical model. Sanchez states that: "The major assumption in studies of services and severity of mental illness.... is that the psychoanalytical model works with the Chicano community. A second assumption is that the Chicano community perceives mental illness in exactly the same way that the dominant society perceives mental illness." (Sanchez, 1971, p. 8) He feels that if a psychoanalytic model is applied to a culture based on humanism, the logical result will be both a high incidence and greater severity of mental illness. Johnson too takes issue with the medical model and states that: "The present medical model approach to 
therapy, a sickness model which is morally and spiritually bankrupt, with its emphasis on diagnosis, specifications, and artificially unauthentic neutrality, tend to fragment and destroy Mexican-Americans' self-actualization and selftranscendental notions of living." (Johnson, 1972, p. 7)

It is this study's contention that just as a traditional mental health model appears limited when applied to a different chlture (Mexican-American), so too may health delivery services be overlooking a considerable segment of the population by refusal to address itself to the concepts of curanderismo. Thus, Sanchez's two assumptions can be applied to the notion of health and illness. The assumptions would then be (1) that the Mexican-American community adheres to the germ theory of disease, and that (2) this same community looks at disease or illness in the same manner of the dominant society. There is considerable evidence that these assumptions do not hold for the entirety of the Mexican-American community.

From their viewpoint, the following are very reasonable assumptions :

One Chicana felt that many Mexican-Americans of lower economic status look at physicians with considerable suspicion and hostility, for to say that germs that cannot be seen, still exist, is stretching the imagination while bringing in considerable dollars for the doctor. Curanderas charge a small fee or accept a gift of whatever 
a person can offer. A curandera knows what the problem is and does not need to consult books and look at X-Rays. Doctors generally lack the knowledge to treat diseases of supernatural origin; curandexas petition God for help while a physician ignores this type of divine help.

The difficulty, then, is to insure not only that people have access to medical facilities, but that once there, they are able to utilize and benefit from them within their cultural context. Cross-cultural sensitivity is demanded of both actors in this very personal drama. For example, effort on both sides need not be wasted when a nurse or doctor advocate alternative treatment for a dehydrated child whose mother is convinced has caída de la mollera; nor does a sensitive nutritionist need to alienate a Chicana mother by recommending use of certain foods during her pregnancy -- foods that folk tradition may tell her are to be avoided. And of course the amount of respect with which the above hypothetical women are treated will have much to do with whether or not they choose to return to the doctor's office or clinic.

So-called modern scientific medicine and curanderismo do exist side by side, and there is little evidence that the Mexican-American population dispenses with scientific medicine in favor of folk medicine. It is not clear, however, how often scientific medicine finds credibility in the virtues of curanderismo. Mexican-American culture does 
recognize that many diseases require the attention of a doctor, and a curandero will unhesitantly send his patients to doctors when his medical system does not apply. And there are cases where a doctor may recognize symptoms or syndromes with which a curandero is better able to deal, and encourages his patient to seek help from the curandero himself. That susto pasado is often known as tuberculosis in the scientific medical community lend's importance to the notion that at times the two disease theories and cultures do, however, conflict. Such a conflict suggests a need for education on both sides, and understanding and appreciation of the attributes of both systems.

\section{Methods Statement}

This study is based upon a proposed relationship between belief in and adherence to curanderismo, or the four cultural illness concepts of caída de la mollera, empacho, mal de ojo, and susto, and the ability to relate to modern scientific medicine. It is both exploratory and descriptive, and as such does not presume to cover all the variables involved. The study further contends that if adherence to folk medicine is an issue among settled-out Chicanos, then it most certainly is an issue that needs to be addressed among the migrant Chicano population.

Although the sample is limited, this study has been a conscious attempt to approach curanderismo from the viewpoint 
of women; they appear to be consciously interested in the health of their households from an everyday perspective.

Kay feels that Mexican-American women

...believe that much illness is due to life habits, So women attempt to control the environment of those who are dependent on them to insure their optimum health, at least to the degree that they feel the situation can be controlled. They have explicit beliefs about the kinds of daily activity, nourishment, rest and recreation which lead to good or poor health. Women are almost solely responsible for the nutrition of family members since women are the regulators of the diet and the preparers of food. When women interpret someone's behavior as indicative of illness, they attempt to discern what the illness may be and what care will restore health or at least give comfort. For Niexican-American women, then, illness is a major daily concern. (Kay, 1972, pp. 6-7)

The Population

In order to study curanderismo and its implications, members of the Chicano population of a rural area of about 9000 -- with a larger surrounding area -- were asked to share their perceptions of "folk" or cultural medicine. Since preference is so individual, one cannot assume that one term -- Chicano, Mexican-American, or Mexicano -- will be acceptable to all those of the Spanish-speaking population of the area. The choice of word usually seems to reflect differences in views, concerns and goals. Reports from Chicano conferences indicate that people identifying themselves as chicanos are concerned with pluralism and with the recognition of specific cultural values in chicanismo, while those identifying themselves as Mexican-Americans 
would be more concerned with assimilation and acceptance into the mainstream culture. In addition, Mexican-Americans could be chaxacterized by a wish to maintain the status quo, while Chicanos would tend moxe toward social action, unionization, and organization to reach their goals.

Mexicano is a term that many of the community members use in reference to themselves. One Mexicana felt that all three terms meant the same, or referred to the same people, and that it did not make much difference to her which she was called. She recognized that it did make a difference to her children, and that they preferred the term Chicano, while she and her husband refer to themselves as Mexicanos. The terms Chicano, Mexicano, and Mexican-American shall be used in this study with the recognition -- and apology -- that such a decision will not please everyone.

The majority of the Chicanos in the rural area appear to have originally come from Texas, and in particular, the Rio Grande Valley. Although some may have left Idaho or Washington to settle in the Oregon area in question, they apparently went to these states after leaving Texas. Few Mexicanos in the area are from California or New Mexico. Many are ex-farm workers who "settled out" of the mainstream when abfe, perhaps due to the hectic life, and realization of the troubles their children would have with school and community due to the constant moving involved. For many, the town in Texas where they and their family 
were born had special significance, and was always returned to no matter how far the distance travelled to pick the next crop.

There are no statistics on population regarding the area in question other than those for the Oregon County as a whole: In April of 1970, 4,215 people out of a total of 151,309 were designated those of the Spanish language -2.78. There appears to be a much higher percentage of Mexicanos and Chicanos in the area studied, without available statistics to back this up. Some Mexicanas consulted estimated their number at around 2,000, but it should be emphasized that this is guesswork and more than likely reflects a view of their particular community area only. A Chicano health official estimated that there exists a population of nearly 10,000 Chicanos within the 10 mile radius that the clinic serves. In the summer, he estimates that the number jumps to around 18 to 20,000 .

Data gathered represents a time span of July, 1973 to April, 1974, with the intensity of research varying at different stages. The researcher's own role began in July by visiting a summer migrant health clinic, and expressing interest in curanderismo and specifically, mollera calda, empacho, mal de ojo, and susto. Very important, a "feel" for the subject was made possible through the participation of the Chicana health workers and aides employed at the 
clinic. Talking took place in an informal manner and the researcher fitted into the health workers' schedules.

From October, 1973 to March, 1974, the researcher spent one day a week at a clinic in Marion County, Oregon, in the capacity of a mental health worker. A further opportunity to understand the culture was thus obtained by working with Chicana and Anglo health workers on behalf of the patient population. The researcher's ability to speak Spanish was extremely helpful in this regard, as was the willingness of the Chicana personnel to share their culture with the researcher. Data gathering grew increasingly extensive as the understanding and trust level grew. Permission was requested of health workers and community members to use the information volunteered in an anonymous manner.

The clinic is located on a well-used street of a rural town, and is housed in a fairly modern, former church building of two stories. All contact with patients is conducted downstairs, while the second floor is used for office space. As one enters, there is a reception counter with bi-lingual workers to help orient patients, two small rooms for interviewing new patients, a fairly large waiting room, and a pharmacy. Down the hall one encounters a smaller waiting area, the exam rooms, the nurses station, the laboratory area, and an outreach or nursing referral room. Colored arrows extending the length of the hall help orient the patient to the area sought. The clinic serves a Chicano, 
Anglo; and Russian population and employs a staff of approximately forty-seven people; twenty-seven of whom are bicultural, bi-lingual. (One of the nurses is Russian, and bi-lingual; one of the Anglo doctors speaks Spanish.) The clinic currently services about 85 people a day, and serves a Chicano population of around 10,000; a number that greatly increases during the summer. It is difficult to estimate the total number served by the clinic since it is relatively new in operation. A low figure of last year would be around 13,000 .

Chicana health workers present a group with an age range of approximately 21 to 58 years, and many are settledout migrant workers. They are all bi-lingual and of course represent different degrees of acculturation. The majority maintain families as well as their work, and all are local community members. They are skilled in nursing, out-reach work, reception and facilitation of patients, laboratory work, and medical records. They are crucial in setting a warmer, bi-cultural atmosphere at the clinic in question. The researcher's exchanges with Chicana health workers took place primarily in the clinic, whenever someone had a free moment, a break between patients, or a lunch hour. At these times discussions took place either with groups or individuals. The researcher was also oriented to parts of the clinic's functioning -- such as the Well-Baby clinic -through the help of Chicana and Anglo health workers. 
Anglo nurses represented an age range of about 21 to 30 years, and were often employed through the VISTA program. They were often helpful in a cross-cultural context. Anglo doctors ranged from age 26 to 35 and were helpful in terms of the medical aspects of cultural diseases. At times short interviews were arranged although the primary means of contact was conferring with staff between patients.

Mexican-American patients were generally an older group, around 35 to 55 years, and were spoken to at the clinic or on home visits. There was no mixture of work and research; rather than specific data, the researcher was able to observe and experience a different manner of looking at life.

Community members were either women who formerly worked at the clinic, or (1) the Señora who considers her curing knowledge to be within the realm of home remedies, and (2) the Señora whom some consider a curandera. The above people were spoken to in the community.

The students consulted were visited at a nèrby Chicano college, and talked with as a small group. Some of those personally spoken to were among those who returned questionnaires. There were no Chicanos (masculine gender) among the Chicanas consulted, and their age range varied from around nineteen to thirty-five years. A short questionnaire (see Appendix) telling four stories helped on background information. It was distributed only to students 
who were willing to take part in a social research project, and was used in Spanish and English. The stories were composed by taking the most common characteristics of the four illnesses in question (calda de la moliera, empacho, mal de ofo, and susto) and there was particulax interest in how respondents would picture the interchange at the doctor's office.

The questionnaire was translated into Spanish by a Chicana student at the Chicano college, and it was requested that she use an informal style of everyday language in her translation. It was distributed by a chicano professor at the same college who requested help in participating in a social research project from a class. A stand with questionnaires and an invitation to participate in the study was also placed in the main hallway of the Chicano college: This approach did not elicit any responses.

For all groups consulted, a request for help in understanding curanderismo (and/or medical implications) and applying the information to cross-cultural understanding was generally what elicited response. Communication was carried on personally and in an informal manner. There was no use of a control group, and information was gathered where it was offered, randomly and on a volunteer basis. Personal sharing of information was usually recorded in a participant-observer manner, notes were sometimes taken during the talk, and a write-up usually followed the talk. 
Iimitations of the Study

It should be noted that no attempt was made to understand Anglo folk-curing and its impact on Mexican-Americans although it is undoubtediy present as seen in drugstores, television advertizing, Vitamin $\mathrm{C}$ and Vitamin $\mathrm{E}$, and the health food store fad. Thus to isolate curanderismo and treat the topic as though folk healing were a very different custom from the dominant culture would not be accurate. In. addition, since curanderismo is an integral part of the entire Chicano culture, it cannot be fully understood without an understanding of the entire culture -- perhaps particularly the family. The above is a wide panorama to which this study does not give justice.

Another basic limitation of the study was that with the exception of Chicana students, contact was made primarily with health personnel and patients, who by virtue of their presence in a health care setting may have accepted that orientation to some degree. This leaves untapped a potential segment of the population whose beliefs in curanderismo or fear of modern medicine, etc., do not allow them to even approach a health clinic. Then too, although not all information was gathered at the health clinic setting, it may be reasonable to assume that some of what was gathered was subject to censure simply due to the setting.

Very important variables that the limitations of time 
of this essentially exploratory and descriptive study could not permit are:

(1) The degree of acculturation

(2) Socio-economic level

(3) Language facility

(4) Type of community informants grew up in and for what period

(5) Lack of male input -- information is primarily from a female point of view. This was intentional since a major focus was mothers and their children.

The size of the sample was limited since information was gathered only where people volunteered; a broad variety of age is also lacking. The fact that community members were responding to an interested Anglo may have influenced responses, as well as the degree of trust built up in the relationship with the researcher. The questionnaire may exhibit a difference in response since it was distributed by a Chicano.

The researcher was unable to talk directly with a widely known curandera or curandero, and this in part reflects some of the difficulty an Anglo encounters when inquiring about curanderismo. It was possible, however, to talk with a community woman who has a great deal of knowledge about herbs and home remedies. Through personal referral from a Chicana, it was also possible to talk with a community resident whom some consider a curandera. Most Mexicanos do not expect Anglos to believe in mollera caída, 
empacho, mal de ojo, susto and other beliefs, and much less show an interest in them. Curanderas have been slapped with malpractice suits and are now leary of sharing their knowledge with interested Anglos. This researcher was refused the opportunity to talk with a woman formerly on the teaching staff of a Los Angeles hospital as an instructor in curanderismo because of membership in the dominant Anglo culture. With time, and the building of relationships and trust, it would be possible to directly speak with curanderas. 


\section{FINDINGS}

View of Curanderismo In The Community

The following pages concern data that emerged from talks with community members in the Marion County area in question. The major groups or individuals who offered information were (I) Chicana and Anglo health workers,

Chicana patients, (3) Chicana students, (4) a MexicanAmerican woman with extensive knowledge of herbs and afflictions and who does not call herself a curandera but rather classifies what she knows in the realm of home medicine, and (5) a Mexican-American woman who is considered by some to be a curandera, who refers to the importance of Dios (God) in her work, and who seems unsure as to what to call herself in her healing role. She is also a seamstress. She learned treatments from her mother, and she charges a small fee of two dollars. The room in which she works contains numerous statues and pictures of saints, as well as a crucifix. The effect, with clean white sheets on the bed and a clean white cloth draped over the end of the bed, is that of a small chapel or religious area. This woman does not possess any formal degree although her mother, a curandera, did have such a diploma. She does not read or write English or Spanish; she knows what to do for a patient after she asks, "Cómo te encuentras, cómo estas". (How are 
you, how is it going.l one is treated very cordially and with respect upon entering her home.

Caída de la Mollera: The least amount of information was obtained in reference to molliera: calda although everyone spoken to knew what it concerned, and could explain the affliction. Two women around the ages of forty and twentyfive, recognized mollera calida in their own children and did not appear to consider it an especially serious occurrence. One woman said that when her children were young, she used to put oil on her thumb, and push up on the child's palate; she would then shake her child toward the side and down three times. The younger woman considered the symptoms of mollera calda to be among the usual diarrhea and fever symptoms that often affect young children. She stated that she would always try home remedies before taking the child to a doctor, and that depending on what was wrong with a child if symptoms persisted, would either approach a doctor or community person with knowledge of massage and herbs. In her own home she has been able to effectively stop diarrhea with a mixture of the water skimmed off after boiling rice, and sugar. She will also take the child off his milk when treating diarrhea. Other women consulted felt that taking the nipple away from the child too fast can cause something funny, with the suction; one must suck (chupar) on the soft spot with spit, push the upper palate three times, and tap the heels 
of the child. When approached on the topic of curanderismo, and especially susto, mollera caída, empacho and ojo, other women chose to respond to one or two cultural diseases, and not necessarily caía de la mollera.

The woman who considers her knowledge to be within the range of home remedies and who shall be referred to as Senora Elvira, said that while she used to cure caída de la mollera, she no longer believes in it. Senora Elvira did not elaborate on the reasons she no longer believes a blow on the head can cause the affliction. Antes (before), she used to cure mollera caída by putting oil on a finger and pushing up on the palate while pulling lightly on the child's soapy hair. She would also hold the child by his heels and tap three times on them.

An Anglo doctor consulted stated that in a dehydrated child, the fontanel is sunken, and that with respiration, crying and sucking, the fontanel can alterate an up or down position. Since the fontanel can also bulge when a child is crying, the practice of turning a child upside down and shaking him three times by the heels may induce him to cry and return the fallen fontanel to its normal position.

One of the stories on the informal questionnaire describes mollera caída:

A mother was nursing her baby girl and someone made a loud noise behind her; she turned around very quickly and the nipple was pulled from the baby girl's mouth. Later in the day it seemed that the little girl had 
trouble sucking, had diarrhea, cried a lot, and had a high temperature. Her mother couldn't be sure, but she thought her head looked bumpy. Since the symptoms continued, she took her girl to the doctor the next morning.

What do you think happened at the doctor's office? What do you think the doctor would tell the mother was wrong with her little girl?

How would you help the child?

would you change this story in any way?

Respondent number one is twenty-seven years old, and originally from Texas. As all of the respondents, she speaks both Spanish and English. She apparently Iived in both a town and a farming area. As regards the doctor, she stated: "He wouldn't know what it was unless it was a virus." She would not change the story in any way, and would help the child by "Llevarlo que le levante la moyera (mollera)". (Take him and have someone raise the fontanel.) Translations are researcher's unless otherwise noted. Respondent number two is forty years old, from Progreso Texas, and grew up on a rancho (small farm). She stated:

Púes éste niño lo que le pasó fué que su madre al soltarle el pecho de repente se le callo la Moyera $y$ por eso despues tenía dificultad para momar y la diarrea viene de la misma calda de la moyera y eso el doctor no cura as 1... puede darle los mejores medecinas pero mientras no le levanten la moyera, el estomago no se le compone. (Well, what happened to this child was that his mother upon pulling suddenly away. from him, his fontanel fell, and because of this later he had trouble sucking and the diarrhea came from the same fallen fontanel.. and the doctor won't be able to cure it like that... he can give the child the best medicines but as long as they don't raise the fontanel, the stomach won't right itself.) 
The third respondent is from Rrogreso, Texas, twentysix years old, and from a farming environment. She stated: "I would help the baby girl by curing her of a fallen mojera (mollera) because all the symptoms she had were cues of a fallen mojera."

The fourth respondent is thirty-one years old and from a city environment, Texas. In response to the question "What do you think happened at the doctor's office?" she stated, "Doctor examined baby and couldn't find a real sickness". She thought that the doctor would probably tell the mother that what was wrong with her little girl was "Probably that she had eaten something not agreeing with the baby's stomach." (How would you help the child?) "By curing her de empacho." (Would you change this story in any way?) "Yes. First tell the mother that the child was suffering from "empacho". Then take the child to a lady who knows how to cure it and probably the baby will be okay from there on."

Respondent number five did not state an age although the researcher would guess she is around thirty-five years old; she is from Texas but did not state what type of community she came from.

I think doctor don't know about a bump on the head. This is a cradle bump. .he would give some medicine for diarrhea. OK. A cradle bump in Spanish is Mollera Calda, and when this happens to a child he gets this symptoms of diarrhea, cry, high fever. The best thing to do is turn the baby upside down and stick one of your 
fingers through (intol his mouth and push with your finger into his tender throat. Or even use a spoon to work on his throat; and not any person can do this kind of work, only curandexas.

\section{Empacho}

Two Chicana health workers in satellite clinics informed the researcher that they saw quite a bit of empacho at the clinic; the patients either referred to their stomach difficulties as such (empacho) or the health workers themselves would identify the condition. (This was not necessarily a public identification.) It should be. noted that the above information was gathered in July, at a peak period for migrant workers.

One infopmant, clara, has a little girl who when she was younger had diarrhea for a very long time. The diarrhea was so severe and lasted for so long that at one point Clara took her to the emergency room of the hospital -- she was afraid the girl would dehydrate. Doctors to whom she took her little girl "cured" her for a while, but the trouble always came back. Finally, clara convinced her husband to let her take the child to a local curandera. Clara thought she maybe had empacho but the curandera checked her for mal de ojo and mollera caida anyway. Then the curandera rubbed an egg over the child and repeated this for three days, and had her drink a certain herb mixture for three days as well. Clara said her child expelled all sorts of mucus and congestion and has not had any trouble since that time. The 
child is now nearly two years old.

Another person related her experience with her sevenmonth old baby boy. His symptoms were diarrhea and a lot of vomiting. Doctors had tried six months without success to cure the child. Although she did not believe in it very much she decided to give him the cure for empacho. She rubbed him on his stomach two different ways (from the sides in toward the middle of the stomach, and from the top of the stomach toward the direction of his feet); turned him over on his back and rubbed him in the direction of his feet only; and then pinch-pulled the skin above his backbone. "You hear a crack or a snap and then you follow twice more down the back (más abajo) doing the same thing." She hesitated before doing the pinch-pull part because she did not think that she knew enough to do the whole treatment. However, his symptoms stopped and she feels that she cured him. The same woman said that some people think they can tell if a child has empacho by looking for and feeling little bumps on the wrist area or the veins of the leg; she does not agree with this method.

Some of the Chicana students consulted felt that a mixture of the following helps to cure empacho: estafiate (wormwood), corn husk and one teaspoon of olive oil. These women were of the opinion that the chewing and swallowing of gum sometimes causes empacho in children.

A Chicana health worker related that she uses lard 
with which to massage the child on both sides of the body. The stomach she then rubs with an egg and wraps a towel, sort of like a bandage, around the area where the egg breaks. You give the child cod liver oil afterward. This woman explained that you do the pinching and the pulling of the skin from the shoulders on down to the colíta ("tail" or lower back).

A health worker with years of formal education made the comment that he did not see why doctors refused to recognize empacho since it made sense to him medically (i.e. the concept of a ball of food sticking to the intestines and not being passed normally through the body.) In addition, a doctor commented that the ingestion of liquids or teas for the treatment of intestinal disorders made sense to him medically.

Senora Elvira expressed the opinion that empacho occurs when a baby is teething for he often swallows quite a quantity of saliva. Due to the amount of mucus present with the condition of empacho, you need to give the child a purge (pulga). Senora Elvira makes a purge of aceíte de comer (cooking oil), aceite de castor (castor oil) and castoria (a patent medicine used as a cathartic). She gives the above mixture to the patient with tea; she does not believe in pulling the skin on the back to treat empacho. Further information on the empacho condition was gathered from responses to the questionnaire story: 
A child of three seemed to have an upset stomach because he complained of it hurting a lot. He also had diarrhea. This trouble continued for three days and then the mother took him to the doctor because he wasn't eating well and his stomach seemed upset.

What do you think happened at the doctor's office? What do you guess the doctor told the mother was wrong with her little boy?

Would you change this story in any way?

What do you think would help the child get better?

The first respondent said that she thought the doctor would give the child a check-up and tell the mother that he had a sort of virus. She would not change the story in any way, and to help the child get better, she would "cúrarlo de empacho" (cure him of empacho).

Respondent number two:

Pués éste niño lo que pasó fué que comió algo gue no le gusto; le calló mal al estomago. Se empacho; por eso la comida le repuniava; para que se le quite eso es necesario; lavarle el estomoguito; darle una cucharadita de acelte de olivo con poquita sal; hay unas llervitas (hierbitas) que son nuevas para el empacho que se las de como té.. esto lo digo yo porque yo se las di a mis hijos cuando estuvan chiquitos que se me empacharon..que no recuerdo el nombre de todos los llervitas (hierbitas).

(Well, what happened to this child was that he ate something that he didn't like and it didn't agree with his stomach. He got empacho; because of this, food didn't appeal to him... so that he feels better you have to clean out his stomach. Give him a teaspoon of olive oil with a little bit of salt... there are some new herbs for empacho that you give in tea form... say this because I gave them to my children when they were little and got empacho...I don't remember the names of all the herbs.)

The third respondent thought that nothing happened at the doctor's office and that perhaps "he didn't know what 
was wrong with the little boy"... She would change the story and "cure him of empacho".

The fourth respondent equated the story of empacho with that of moliera caída and said she would respond the same way as she did for mollera caída.

Fifth respondent:

OK. Doctor's orders to mother: Don't give the child any food, only liquids, tea, skim milk, or bananos (bananas). So what this kid has is empacho and empacho is something that happens to children when they eat beans, corn.. and their stomach is not used to it...or other kinds of foods. So I would cure him by stretching his spinal three times, rubbing him with some olive oil... and after that I would give him a herb..combine it with olive oil: This herb is called estafiate (wormwood). In order to work you have to burn this herb and make it into a powder and give it to the child.

Mal de ojo

The students consulted had varied opinions about the subject of mal de ojo. Some believed in it, some believed in ojo for others but not for themselves, and one woman of twenty has both given and been afflicted with ojo many times. One student affirmed that the person who gives ojo will often have a headache. There was consensus among the women that part of the treatment consists in making the sign of the cross with the egg and then leaving it under the head of the bed (bájo la cabesera) for the night. In the morning, an egg that is slightly curled around the edges shows evidence of having been "cooked". The women noted that sometimes the fever gets too high when a child has ojo and 
the brain sort of "cooks".. This condition is called cesos. Maria related what happened when her brother's daughter got sick. The doctors did not help and the family was becoming worried about the little girl. Maria's mother wanted to cure the girl for ofo but her son, Maria's brother, did not believe in it. Without the brother's knowledge then, the little girl was brought over to her grandmother's house so that the woman could pray and use the egg involved in the cure. This worked; the child was cured.

A health care worker related an experience with ojo that involved her two-month old sister. "My grandfather was a barber and he had a customer who was said to have strong evil eye. Grandfather kept talking about how pretty his little granddaughter was and this man wanted to see her. My mother did not want this man to see her daughter because she knew about his ojo, but finally she took her daughter over to show to him." she then returned to her house. When her father (the grandfather) came home for lunch he heard the baby crying and told his daughter to go pick her up. The mother said "Oh, she's alright", but picked her up to see and found she was very hot with a fever. She also began vomiting; the took her to the hospital but she died on the way, She would be nineteen if she were alive. An autopsy was done and nothing was found wrong with the girl; they decided that it must have been mal de ojo.

Another Chicana health worker, Alicia, explained what 
had happened to her own daughter at the age of four months. Alicia's cousin had a daughter who had died at an early age because of cancer of the eye or a malignancy. Anyway, Alicia's daughter looked very much like the cousin's child who had died and when the cousin's husband saw Alicia's child, he told his wife how much the two children looked alike. So they asked if they could visit with Alicia's daughter for a while. Alicia gave her daughter to one of their older girls who came to fetch her and the baby spent a half hour with the cousins. When she was brought back, she seemed kind of upset; Alicia thought she was hungry and so fed her and put her to bed. Later, Alicia and her mother were talking and they heard the child breathing very heavily. They went in to look; Alicia's mother thought it was because Alicia had been giving the child a bath right before the cousins wanted to visit with her, but Alicia didn't think so since it was a warm day when she bathed her and the door had been open. Later the child woke up crying, was restless, and was breathing even more heavily. Soon she had a strong chest cough (estaba quejándose) and her eyes were closed. Alicia took her to the doctor then because she sounded so ill, but the doctor found nothing wrong physically although he did think the breathing was abnormal. Alicia returned with the still afflicted child and found her cousin and the cousin's husband waiting for her. The couple had come by to visit and were surprised to learn that the child who had 
been so healthy while visiting them had been taken to the doctor. They thought maybe they had given the child mal de ojo and so had waited to help cure the baby. The husband took off his shirt so that he could use the shirt-tails to rub all over the baby and his wife touched the child around the head and forehead. While they did this they talked to the child until finally she went to sleep. The adults stayed around talking and were still talking when the child woke up; she was all right.

Alicia had a friend who was aware that she had a powerful glance. One very hot day she and her friend were walking in the city and saw a young man carrying a big block of ice. As he came closer, her friend said "I hope it breaks so we can get a little piece". As he passed, the ice block simply broke into little pieces and fell from his grip. It appears that some people are aware that they have a particularly powerful glance and take care to protect others from it. For example, one woman who knows she has a lot of strength in her eyes just makes it a point to touch a child or object that she admires.

An older woman experienced ojo herself when she was pregnant. She visited some friends of hers, and the husband of the couple did not say anything to her, but did to his wife. "He thought I looked so cute in my maternity outfit. I was so big you know." She returned home and pretty soon she was dizzy, weak for three days. Finally, 
she got a friend of hers to do the cure for ojo because she thought that might be it, and it was not until later that she mentioned it to her friends. The husband explained that he had mentioned her looking so cute to his wife, and they thought it was probably they who had given her mal de ojo. A friend of Alicia's was working in the fields and the Anglo foreman drove up with his wife and baby boy. The parents put the child in the front seat while they went off to do some things. From where Alicia's friend was working in the fields, she could see the child right across from her and he was so cute that she wanted to touch him. The child was about six or seven months old. After a few minutes, the child started vomiting and since he had been fine when the parents drove up, they were worried and took him to the hospital. The friend was sorry because she thought that she probably gave the child mal de ojo; she wanted to touch him and had not been able to.

Perhaps the most dramatic instance of mal de ojo related was the following:

A woman was walking down the street with her daughter, a beautiful. little girl of four or five years old. A second woman, dark-skinned and with curly hair, perhaps part Puerto Ricana (from Puerto Rico), was walking behind the first woman and admiring her daughter. She asked permission to touch the little girl and her mother refused. The second woman insisted, saying that she had mal de ojo really bad, and thought that she had better touch the little girl. The mother still said no and walked on. It turned out that they were going to the same dressmaker's house. As the little girl walked up the stairs she fell down and began to 
vomit; she yomited so severely that she yomited up her insides and she died on those steps. Her mother blamed the strong ojo of the dark woman, because her ginl was fine before.

This experience was told by a woman who is a friend of the mother and knows that such an event did occur.

As regards treatment procedure and the cure of mal de ofo, the following information was gathered from interviews. When the diagnosis is done, and if the person has ojo, the egg will show stripes of white going down toward the bottom of the glass, as well as a white spot or "eye" in the middle of the yellow yolk. Three little crosses from broom straw are made and put on the egg; after spending the night below the person's head (under the bed), the mixture must be thrown out early in the morning in the direction of the sun rising.

One woman talked with said that she felt most Chicanos consider mal de ojo a thing that happens to children when they are little; it doesn't happen that often with an adult. A Chicano consulted said that he objected to people latching onto what appears to be the "mystical" angle of mal de ojo -- and therefore discrediting other components of the approach to mal de ojo.

Most of the women consulted had personal experiences with mal de ojo and had either been afflicted themselves, or had given ojo unwittenly to people, and/or affected objects with their glance. 
The following story on the questionnaire permitted further information to be gathered concerning mal de ojo:

A young mother with a seven month old baby boy went to visit relatives. Her uncle admired the baby like everyone $d d^{d}$, and he didn't touch the child. The mother and child returned to their house and later that night, the child seemed fussy, cried a lot and even got a fever. The baby wasn't any better the day after the next and so the mother took him to the doctor.

What do you think happened at the doctor's office?

What would the doctor tell the mother was wrong with her son?

would you change this story in any way?

How would you help the baby boy?

Respondent one thought the doctor would give the child a check-up and would tell the mother that he had a virus of some sort. "A Mexican would say that it was because the uncle didn't touch the child, ojito. Take him to the uncle and have him touch the baby."

Respondent two:" " "Pués esta historia según entiendo es para los que son crellentes del ojo pero yo no creo en eso' ni ningunes de mis parientes han creído en eso pero si hay gente que tiene esa creéncia." (Well, as far as I understand, this story is for those people who believe in ojo...but I don't believe in this and neither do any of my relatives; but yes there are people who do have this belief.) This story was not included in respondent number three's questionnaire.

Respondent four thought that the doctor "Examined the baby and found nothing was wrong". The doctor would say 
"Probably that the child was catching the flu". As regards changing the story: "I would change it a little bit, but telling the mother the baby was sick from "ojo". First of all go through all the procedures in curing the "ojo". Or get the person who made the "ojo" touch the child. If the mother didn't know about the "ojo" I would explain it." The fifth respondent:

The doctor would say he seemed fussy but I'll check him by taking hìs temperature in his rectum, and maybe might make him cry more, and then order the mother to give him simple aspirin. In my case I would go and look for that person, and make him touch my baby; and if I could not find that person, I would bring down his fever by making the cross (sign of the cross) with an egg, and then break it and set the egg in a glass of water because this feeling or symptom of the baby is mal de ojo. This is my knowledge.

\section{Susto}

An interesting conversation with the student respondents began with a woman making a joke about how the officer who had stopped her and given her a ticket had given her susto. Appreciative laughter greeted this joke.

It was explained that generally susto is when one has dizzy spells, no appetite, and feels weak all over; what an Anglo doctor might describe as nerves.. There is also a sort of empty, fallen feeling to the stomach.

Gloria, a former health worker, had a personal experfence with susto just after her grandmother died. Gloria's forty-year old cousin visited her when he was drunk, 
and was verbally abusive to her and rough. Gloria had just , recently delivered a child and the baby was there with her. When hex cousin came in yelling at her, she felt something like a wave pass over her body, from the head on down; almost like a shiver. This also produced uncomfortable feelings in her stomach. From that time on she had symptoms, and went from 154 pounds to 108 pounds. Gloria was sick nearly a year and let herself go too long without seeking help. She now weighs 124 and has never regained the weight. She did not believe in susto before her experience, but she does now. A friend convinced her to go see a curandera and it was this woman who cured her. The curandera brushed her over with herbs and said prayers; Gloria talked over what she thought had happened to her with the curandera. Her cure took longer than three days because she had let it go so long. She was around twenty-four when the incident occurred, and now is thirty. In Gloria's opinion now, it is the prayers that make the difference in the curing of susto.

The questionnaire regarding susto reads as follows:

A woman was walking to the store one day and saw an accident happen just two blocks from her. One person was serioussly hurt and taken to the hospital; two others got bumps and small cuts. She went on to the store finally and when she returned she sort of thought she was pretty tired. She did her usual work around the house, greeted her children and husband and went to bed early. The next day she felt restless and didn't know why, and she was still very tired; she also didn't feel like eating very 
much and her husband noticed and asked if anything was wrong. She didn't think anything was wrong but couldn't understand why she was so tired and restless and didn't feel like eating. After three more days of this, her next door neighbor who was her comadre convinced her to go to the doctor.

What do you think happened at the doctor's office? What do you think the doctor told her was wrong with her?

How would you help this woman get back to her normal state?

Would you change this story in any way?

Respondent number one: The doctor "couldn't pinpoint her trouble; probably ask her to come back within a day or so if she still felt the same way. Cúrarla de susto (cure her for susto)".

second respondent: "Pués ésta sehora lo que le pasó fué que se asustó; pués eso no lo cura el doctor; pués necesita buscar una persona que sepa curar de susto para gue la cure y le pueda aliviar." (Well, what happened to this woman was that she got susto -- became frightened or shocked -- and a doctor doesn't cure this... so you have to look for a person who knows how to cure susto so that the person will cure her and she will feel better.)

The third respondent did not feel that anything would happen at the doctor's office ("Nothing"). She felt the doctor "Didn't know what was wrong. I would help the woman by curing her of susto or espánto as a lot of people say". Would you change this story in any way? "Yes. In my own way as I know best." 
Respondent four thought that the usual examination

would happen at the doctor's office and that the doctor would say that she should probably rest more. She would "Tell her to go and get cured from "susto". If it's "susto", take her to someone who can cure it and she will be alright".

Respondent five:

The doctor would say they were nerves. He would suggest to her to take it more easy. He would say are you having problems with your husband; try to go out more often. I would say that this is susto and susto is a very dangerous thing; some people get T.B. out of this susto. So curanderas usualily cure this symptom by barriendo la persona con ruda, un chuchillo o un blanquillo si no hay ruda. Por tres noches a la semana, lunes, martes, viernes-al tiempo de barrer a la persona se le rezan tres credos y despues se le da una taza de te de llevanize (hierbanis). (So curanderas usually cure this symptom by brushing the person with the herb rue (Ruta graveolens) (Kay, 1972, p. 167), or a knife or an egg if there is no rue. You do this for three nights of the week; Monday, Tuesday, Friday--at the same time that you brush the person you say three Apostles Creeds and after that you give the person a cup of tea made out of hierba anis (anise or Pimpinella anisum). (Kay, 1972, p. 166)

La Senora Elvira related that there is a temperature with the condition of susto, and that a person's bile will start spreading; the patient cannot eat and throws up. A person will also be quite sleepy and will need to sleep a great deal. The spirit leaves when someone has susto. The sleepiness usually comes around Il a.m. and the best time to do the cure for susto is at noon. 
Miscellaneous

In the course of talking with community members about mollera: caída, empacho, mal de ojo, and susto, other beliefs and practices were sometimes mentioned that have significance for health delivery services as well as mental health services.

One of these concerned what course of action to take when a child has a high fever. Several women mentioned that although they knew doctors would say they should bring down the fever with the use of cold, they just could not bring themselves to do so. One woman of 25 said that she makes a mixture of shortening, and baking powder and rubs this over the child's entire body; it brings the fever down. Other informants mentioned a similar mixture (baking powder, shortening and aspirin) and indicated that rubbing this on helps even up the heat in the body. Señora Elvira added another dimension when she said that rubbing the person with lard and baking powder eventualiy causes a person to start sweating. Then she will gradually take off more and more covers as the body temperature begins to return to normal. Señora Elvira does not believe in "echarle hielo a la persona" (suddenly making a person cold). She feels that is the same as trying to put something very hot into the freezer; it coagulates or freezes. "Aśi hace la sangre". (that's what blood does) for the blood is hot when a person has a fever. These approaches to the treatiment of fever may 
relate to the hot-cold theory discussed earlier.

Terisia is a syndrome that can occur when someone close to you dies or moves away. One woman had a niece who was very close to her grandmother. They were separated through moving and the niece became sad, "you talked to her and it was a.s though she wasn't even there... she didn't want to do anything...". The woman related that the grandmother was similarily affected. She said the cure for this affliction was a certain red-orange bead from Mexico that was worn around the neck in a sort of necklace. The name for the beads was coxales and both the niece and the grandmother wore them. Another explanation for terisia was that a child turned inward if he did not feel warmth and care from those around him. He will spend a lot of time by himself, perhaps pinch himself for no reason, etc. Because his heart is sad, one must dress him with something red; an alternative is to give him a clove of garlic to peel instead of pinching himself. A woman of twenty-four remembered that when she was growing up, her sister once wore red for six weeks; she did not recall the reason.

The role of a sobadora was mentioned. She is considered a very useful person in the treatment of massage and relocation of bones. However, if you have a broken bone, she will not treat you, but will send you to a doctor. One young woman said that she would be much more likely to go to a community sobadora she knows than consult a doctor if she 
hurt her ankle, leg or wrist, The sobadora would employ massage and the young woman would leave with the hurt area feeling much better; she; was unaware of what a doctor would do in such a case. A comworker suggested that a doctor would advise her to stay off of a hurt limb, or simply not use it.

Latido is seen as a kind of emptiness that occurs when one does not eat. The stomach starts jumping and a pulse is very noticeable in the lower stomach area. If one were to eat after feeling like this, one would vomit. Examples given were (I) a person in a nervous state forgetting to eat, and (2) a person who had to work in the fields and who did not have time to get his breakfast before going. A curandera would probably give herbal teas to remedy, the situation, and it was thought that a doctor could probably help as well. Another treatment suggested was massage and then applying a poultice to the area. "Latido translates as 'beat' and probably refers to the visible pulsations of the abdominal aorta. Modern medicine recognizes a condition with such extreme debilitation as 'cachexia'." (Kay, 1972, p. 126)

Although not dwelt on, the belief that a woman should rest for forty days after delivering a child came up several times. Your family is supposed to wait on you, and you should take it easy for forty days. An older woman said that since one's pores are open after delivery and one is 
therefore particularly susceptible to the air, the stomach should be bound. This custom may have given way to younger women wearing girdles after delivery.

Antójo may occur when a woman is pregnant and has a yearn to eat a certain.food, but is denied the food. If she does not get the food, she may go into labor. A good husband would respond to his wife's wishes at any time, but he would be especially careful to do so when she is pregnant.

Findings

An overall view of the data gathered would seem to indicate a fairly high degree of consistency, in that with the exception of one questionnaire respondent who saw empacho and mollera caída as the same affliction, nearly all respondents identified, responded to, and elaborated on the four culturai illnesses. When discussing cultural diseases with community members, attitudes expressed varied from certain belief due to personal experience, to the idea that curanderismo should be scoffed at, or considered beliefs of the uneducated. Between these two views were simple belief in curanderismo, and belief in curanderismo for others but not oneself. Also expressed was the opinion that people used to believe in the four illnesses, but no longer do. Although some respondents cited personal experiences, and professed adherence to one or another of the cultural diseases as well as modern medicine, this study cannot presume to make a statement about the degree of adherence to 
folk beliefs in the oregon community in question. What has been ascertained is that a very small segment of the Chicano or Mexicano community either responds personally or in some way relates to the cultural diseases of moliera caída, empacho, mal de ojo and suisto.

No distinct relationship can be said to exist between adherence to cultural illness concepts and the ability to relate to modern medicine; the most that can be said with an exploratory study is that reaction varies tremendously. A theme that cropped up from time to time was scepticism that Anglo doctors could understand, or know how to treat cultural diseases. The research suggested that a Chicana would not necessarily seek the help of a scientific doctor were she or one of her children to be afflicted with empacho, mal de ojo, mollera caída or susto; nor would she necessarily seek out a curandera. Another variant was that a modern day doctor would be sought after for some, but not all of the cultural diseases. The use of herbal teas and patent medicines either separately or in combination appears prevalent, and although one Chicano health worker estimated that $95 \%$ of community members resort to modern medicine, the data does not indicate that patent medicine, for example, is used at the exclusion of herbal teas. It is not clear at what point women use home remedies (herb teas as well as patent medicine obtained in the drugstorel, seek out kin, or obtain the advice of a 
doctor, sobadora (massager), curandera, or a person knowledgeable in the use of herbs. In other words, more data is needed as to how people are actually coping.

As many fairly acculturated Chicanas responded to this degree regarding cultural illnesses, one is tempted to assume that less acculturated and well-to-do community members are more involved with the cultural illnesses of mollera caída, empacho, ojo and susto. This may or may not be the case. The opinion was expressed, however, that the majority of migrant workers would be more in touch with cultural illness concepts.

Perhaps more important than equilibration over the positive and negative points of cultural diseases is the fact that they are indeed responded to and experienced on one level or another. It is this that has import for modern medicine and health delivery services, and brings up the issue of cultural sensitivity for both Anglos and Chicanos. 


\section{IMPIICATIONS AND RECOMMENDATIONS}

A reliable source considers the oregon community in question to be a fairly conservative one, and one in which there is a high adherence to modern medicine, perhaps $95 \%$. Some acculturated community members are interested in acquiring the more material aspects of Anglo culture and choose to invest in house, car and/or property. There is little information on those in small towns, or those living on a different socio-economic level whose concerns are more with survival.' Nor does this study encompass the migrant population who", as a whole, can be considered in closer contact with curanderismo. The opinion was also expressed that there is no cut and dried adherence to one medical system versus another in the community. This study suggests that the degree of adherence to cultural medicine is a varying phenomena, and as such, any new medical information needs to be flexible enough to fit into whatever type of framework a person, family and community possess.

What can be considered a social and kinship system in Mexico may have become a survival system for the chicano in the United States. Culture determines what values children are taught, what they actually perceive, and how they view such universal experiences as life, death and birth. Those in the child care fields, the mental health fields, and 
medical fields must be able to step out of their own culture and view it form another perspective if they truly wish to address themselves to the needs of Chicanos and other cultural groups. The needs of a people are not compartmentalized and separated one from another. A Chicano consulted felt that the total concept of familia (family) is perhaps the most important experience in life for his people. Although the Chicano family concept has been stigmatized and stereotyped as quaint and "wholesome", it is proving to be the uniting and integrating force in the chicano culture. The concept of familia does not stop with the nucular family but includes a world view that differentiates it from the compartmentalized and fractionalized world view of the dominant society. Hence any attempts to reach the Chicano through health delivery services will achieve limited success until the total problem in all its implications is addressed.

This study has not chosen to romanticise curanderismo, but instead to recognize that both the dominant cultural group and the non-dominant cultural group have much to offer; the whole will grow only by transcending respective cultural fences.

Illness and disease are social as well as biological phenomena. On the biological level they consist of adaptations of the organism to environmental influences; on the social level they include meanings, roles, relationships, attitudes, and techniques that enable members of a cultural group 
to identify various types of illness and disease, to behave appropriately, and to call upon a body of knowledge for coping with the condition defined as an illness. What is recognized as disease or illness is a matter of cultural prescription, and a given biological condition may or may not be considered an "iliness" depending on the particular cultural group in which it occurs ... Mal de ojo, susto and empacho are examples of diseases that are common in Latin America but unknown in the United States--with the exception of the Spanishspeaking Southwest--although the symptoms which give rise to diagnosis of any or all of these are fairly common in this country. What should be done about a given condition defined culturally as "illness" and the proper relationships of a sick person to other people are also culturally prescribed. An individual thus has cultural grounds that enable him to know when he or others may be regarded as sick, something about the cause and nature of the sickness, what may be done to alleviate or remedy the condition, and the behavior of him and of others in the situation. (Saunders, 1958, p. 190)

The above is a fine preface to the topic of cultural perception and the patient-doctor relationship, and takes us back once again to the concept of the family and its role in the illness of one of the family members. As noted, an individual's illness seems to be a matter of concern and involvement for the entire family, and it may be that an individual is not regarded as ill unless the head of the family so interprets and appraises the situation. Health workers may need to expand their networks and realize that the hospital or health setting is dealing not solely with one person but with an entire family. It would seem an oversight not to tap into the rich support system that a family may represent. 
With a personal and respectful approach so important in the Chicano community, the hospital or mental health institution is often seen as a cold and unpleasant place to be avoided if possible. The Mexican-American community long ago built up effective methods of dealing with health and illness in the community - a sort of natural support system that partially resulted from being excluded from the dominant culture's way of solving its problems. It is difficult to discard those comfortable and predictable ways and submit oneself to a relatively unfamiliar situation such as a medical institution or mental health institution where the setting is often seen as cold and impersonal and where medical personnel do not speak one's language. The hospital may also be known to some as a place where people go to die. This belief is common among the Native American and may reflect past experiences when a patient was brought to the hospital only as a last resort and when not a great deal could be done to aid recovery. For some, the experience of a hospital as a place where one cannot be close to friends and relatives may also detour from its use.

Chicanos are very sensitive to the patient-doctor relationship when it is experienced as cool, distant and hurried, with little explanation in understandable terms as to what is transpiring. A potent comparison was made by José, a Mexican-American who spoke to Madsen: 
Both curer and doctor are specialist in curing illness. The curer can treat some diseases and the doctor knows how to treat other afflictions. But the way they feel is always aifferent. A curer cares about the patient and not about the fee. A doctor explains nothing and struts about as though he were a great man and you were only a fool. If you pay a doctor, he doesn't care whethex you live or die. The curer cares. Have you even seen a doctor grieve because of pain you suffer? Have you ever had one comfort you? or respect you? A curer cures because he cares. The doctor cures because he likes money and power.

The curer respects everyone but the doctor respects only himself. The curer will send you to a doctor when you have a sickness he can cure. Once when I thought $I$ had empacho, I went to $a$ curer. He felt my belly and said it was not empacho but something bad in there that must come out. He sent me to a doctor and $I$ went to a hospital and my appendix was cut out. A curer admits there are things he cannot cure and helps you find someone to treat it. Have you ever had a doctor send you to a curer because your sickness was susto? Doctors know they can't treat susto. But they say it is some other disease and give you worthless medicine until you die. And you pay right to the end. Then they sign a certificate saying some disease killed you and they think they are free of blame. (Madsen, 1964, p. 91)

This study does not mean to imply that all doctors fit the above category; what does seem quite plausible and may frequently occur is the refusal to respect and accept the validity of another culture's beliefs. Thus, there may be a tendency on the part of Anglo medical personnel or acculturated Mexican-Americans unfamiliar with curanderismo to characterize chicanos as superstitious or uneducated to continue using their own medical practices in the face of modern medicine which the 
Anglo knows is better. Saunders speaks to this issue in regard to Spanish-American villagers.

What such Anglos fail to appreciate is that Spanish-;, Americans also know their ways are superior and that $\because$ their use, far from constituting neglect of or indifference to the needs of sick relatives and friends, actually constitutes the provision of firstrate medical care. The Anglo may argue that by the pragmatic test of results his is the best medicine and that the Spanish-American ought to have enough sense to see it. But the evidence of the superiority of Anglo medicine is not always available to the Spanish-American in a form that has meaning to him and in any case, what is "good sense" is relative to culture. (Saunders, 1958, pp. 200-1)

Two points can be made here, the first that both systems of looking at disease and health have their "good" and "bad" aspects, and that a flowing between the two would be more desirable than a fight for supremacy; and second, that one cannot assume that what is clear to a person behind one cultural fence is even remotely perceived in a similar manner by a person standing behind another cultural fence. In addition to specific awareness of cultural differences as regards disease entities and their implications, health personnel can learn to be sensitive.

Health personnel can pay attention to the manner in which a person enters the health setting. This researcher has seen Chicano men enter a clinic cautiously, look around to check out the situation, and then step to the side to permit their wife and children to pass through the door. Usually more familiar with his cultural institutions, an 
Anglo will come right in, Health workers can learn to become sensitive to a cautious entry. Also important to note is the age of the potential patient. When an older person arrives with a younger family member who may act as interpreter, it is likely that family pressure caused the elderly person to approach the health setting. One does not know what past experiences a Chicano has had with health settings and health personnel, nor whether such experiences have left the person with a defensive or bitter residue. It is important that clinic personnel get a feel for the degree of assimilation of the Chicano patient, and it is usually important to be able to speak Spanish. (The young are often an exception as regards language.) Time should be spent talking with a person and putting him or her at ease while explaining procedures and their necessity. For example, some chicano men may become anxious because they believe that taking blood for a blood sample will reduce potency. And since mothers do not like to see their children suffer, sensitivity and communication is required when children need to undergo painful tests. An Anglo mother is perhaps more likely to check her own feelings when observing her child in pain because she usually relates what is happening at the moment as being important in future prevention. A Chicana may or may not respect or understand the concept of prevention, and considering the individual, health personnel would do well to explain the concept in an 
unpreaching and unblaming manner.

An issue with cultural implications is that of the Chicana coming in for a pelvic at a health setting. The fear of being examined by a man may be enough to detour a woman from actually placing herself in such a situation. Both clark and Saunders note that it is not without significance that most of the healing personnel in the culture of the Spanishspeaking are women. The Chicana may be used to exposing more private parts to her husband only. Anglos are accustomed, if not used to, the ritual of undressing when going for a check-up; the Chicana may or may not be, and being told to undress in a strange setting in an unsensitive manner by the nurse or doctor could be offensive to her. Octavio Paz makes an interesting comment in regard to modesty and feels it results from shame at one's own, or another's nakedness. Yet it is not the same fear, or being ashamed of one's body that he sees as the North American attitude. Rather, the body reveals rather than hides the private self in a naked state, and modesty thus becomes a defense. Prudence is admired in women, as reserve is in men; women should defend their privacy. (Paz, 1961, p. 35)

Thus the Chicano male may well enter the exam room with his wife, He is not used to leaving her alone with a stranger, and if the doctor is Anglo, further complications may be involved.

It was explained to the researcher that chicanos are 
muy delicádos (very careful, protective) of their wives, and this too then, the health worker needs to keep in mind. There is often a heavy ban against talk of sex in the home -although sexual matters may be more open with the migrant population because of small living quarters -m and this attitude has to do with unwillingness to expose oneself for pelvic exams. A high percentage of Chicanas suffer from, as well as die from, cancer of the cervix, both because of reluctance to submit to a pelvic exam, and because there is little relation seen between a pap smear and prevention. Many people also question the need for follow-up exams -Why wasn't the doctor able to do it all at once? Some patients may begin their follow-up appointments and then slack off because they see that nothing changes, or again, the concept of prevention is not understood. This is especially important in the treatment of cancer.

Another point in patient-medical personnel relationships is the manner of communicating. Courtesy and formality are very important when relating to one another, and a Chicano may be more likely to tend toward an elaborate and indirect means of speech since he takes pride in the art of verbal communication. One also takes care to respect the other's individuality and make the relationship at least appear harmonious. The directness and frankness of the Anglo may at times conflict with the Chicano's manner of communicating. Acculturation is of course a large variable 
in this regard. Also significant here may be that an Anglo could offend a Chicano without being aware of it or directly confronted with his behavior.

Another deterrent to adequate health care is the variable belief in machismo (manliness). For boys and men machismo can support a reluctance to admit to pain or being ill. This means that one may ignore symptoms until they are severe and one is nearly incapacitated. By then it can be much more difficult to arrest whatever disease process had begun. A common occurrence is that a boy does not take care of a problem, for example, a hernia, that might be prevented from bothering him when a man. Also, a Chicano. may be very sensitive about exposing his genitals with a nurse in the room; conversely, a Chicana nurse may feel uncomfortable remaining in the room during such an exam. The propensity for use of salves and/or douches on areas afflicted with venereal disease may result in the belief that one is cured, when in reality, one has alleviated symptoms. Syphilis in particular causes problems because one stage of the disease includes sores which eventually disappear. A Chicano who has applied salve to the afflicted area may conclude that he is cured, when actually the disease has passed to another stage. So, too, a Chicana who employs herbal douches may relieve the immediate symptoms of venereal disease while remaining afflicted. 
One Chicano health official expressed the belief that for many Chicanos; a shot is the equivalent of health, and that shots indicate better quality health care than does the use of pills. Injections are available in pharmacies in Mexico, and it may be that the migrant population in particular is used to being able to request its own health care. People may be taken aback, or offended by being told they cannot have the type of shot they request at an Anglo medical institution.

Kay, a researcher in Arizona, found that most women in Kroeger Lane were reluctant to have their infants receive immunizations before school age because the fevers that sometimes followed the shots were dangerous; also operrant here was that their husbands would not allow it. Kay found the age at which a baby was brought for immunization to the serious communicable diseases of childhood to be the best single indicator for acculturation to western scientific medicine. (Kay, 1972, p. 194) Several health workers consulted said they recognized an unwillingness in some of the women to bring their children in for immunization, precisely due to slight reactions they might experience. Also in operation is the observation that one's mother brought up all her children alive and well without the benefit of immunization; what guarantee makes sense in the light of this fact?

Thus a sфnsitive health worker may choose tó gain an 
understanding of curanderismo and local medical beliefs so that he or she can reach the patient within his own cultural framework while relating that framework to the one of modern medicine. The health worker can thus avoid appearing ignorant, and may be able to sensitively work toward changing some cultural illness beliefs that may be detrimental. Advances in modern medicine are of little use to a population that may reject them due to their mode of presentation, and perception from a different cultural viewpoint.

Although no evidence for such a situation was found in the small population studied, it is plausible that the following situation or a variant thereof could occur among the migrant population in oregon this summer, or in settledout Chicano communities further South.

Unconscious hostility may be expressed in attributing powerful vision to another person even though he is not openly blamed for the damage he causes. Desired avoidance of an individual also may be rationalized on the grounds that the person possesses the evil eye. Mrs. Webster is a kind-hearted and devoted public health nurse whose bustling authoritarianism makes her unwelcome when she visits Latin homes. She is greeted politely but her presence is obviously resented. She is unaware of the fact that she has the reputation of possessing the evil eye and spreading sickness among the Mexican-American children whom she admires. She is the subject of female gossip throughout the Latin community because she behaves improperly and poses a threat to children. "How can we trust her statement that she understands disease and wants to help us?" ... She is either stupid or inconsiderate to admire so many kids when she has strong vision and then not even to try to prevent the sickness by touching them. (Madsen, 1964, p. 76) 
Another potential offending source is the public health nurse who talks about female reproduction and female organs in a direct professional mannex, using specific vocabulaxy. Such a direct approach often offends the Chicana because in her environment she is more likely used to an indirect term such as "female problems".

Another problem that public health personnel must face is the belief that at one time public health nurses were used as government informers of Mexicans who were illegally in the United states following the migrant stream. Trust will have to be re-established.

Important to remember is that health practices do not exist in isolation from the rest of the Chicano culture. Thus religion, diet, social relations, etc., are involved in health and illness. Perhaps particularly in the Chicano community where the family is part of a much larger network that keeps community members in touch with one another, illness cannot be regarded as an isolated factor. Successful treatment must address the patient's environment as a whole, and would do well to collaborate with and learn from the natural help system that already exists within the Chicano community.

clearly there are many helpful recommendations that can be made. Of foremost importance of all of them is, however, the concept of family. A medical worker should often avoid putting a Chicano in a situation where an 
individual decision must be made; it may be preferable for the patient to first consult with family members since all are involved in an individual's illness. Even a mother, for example, may need to consult with hex husband or an elder family member before deciding what course of action to follow for treatment of their child. If family members accompany (as they usually do) the patient to the clinic or hospital setting, it may be appropriate to consult with them about the welfare of the patient. Their cooperation may be crucial, as for example, in the case of a young Chicana with a stomach ulcex who continued to eat the usual diet cooked by her mother who had not been included in on the health plan for her daughter.

To generalize and summarize: When the curandera is involved, the process of diagnosis and treatment takes place in an informal atmosphere where cooperation between patient, family and healer is the norm. Family members know what is taking place and the reason behind certain procedures; they are free to both criticize and offer suggestions. The entire family thus participates in a situation that involves personal and informal relationships, and where diagnosis is fairly easy and swift, and is followed by treatment. Anglo medicine on the other hand is likely to be somewhat impersonal and formal. The patient is generally turned over to the physician who then oversees the diagnostic and treatment procedures, largely without 
advice or suggestions from the patient or his family. Information may be elicited from both, but this is usually for the purpose of understanding the present complaints or filling in a picture of the patient's medical history. Diagnosis may be slow and may depend on laboratory results that are not understood by patient or family; definite diagnosis may also involve placement of the patient in a hospital. All this may take place in the context of new relationships that come across as impersonal, businesslike and frequently unsatisfactory. Whether treated by a folk healer or physician, the range of outcomes includes a patient improving, remaining the same, taking a turn for the worse, or dying. The amount of satisfaction that patient and family get in the medical relationship becomes a very important factor in deciding which type of medicine to select, especially when there is no conclusive evidence of the relatively greater frequency of desirable results when using Anglo medicine. (Saunders, 1954, pp. 167-8)

Although written years ago, Clark's statement has meaning particularly in terms of the cultural framework mentioned. ".Folk belief in the barrio is not a trivial or insignificant element in medical care; it is not merely a remnant of primitive superstition that can be mixaculously dispelled by a denial of its existence. On the contrary, folk medical beliefs form a persistent framework into which new learning must be fitted. New ideas which are incon- 
sistent with its patterin are likely to be rejected as false, or, if there is strong empirical evidence for new ideas, they may be relegated to a special category of disorders 'that doctors know about'." (Clark, 1959, pp. 209101

It is thus paradoxical that we are both the beneficiaries and victims of our culture. We can see an analogy and say that the grace of the dancer is the function of the skeleton; and it is thanks to the skeleton that these graceful movements can be carried out, but the arthritis of the dancer's grandmother--this too is a function of the skeleton. It is the same with a culture--this fixed framework within which and out of which we can develop, but which because it is a fixed framework, may become somewhat rusty and completely paralyze us and prevent us from passing beyond its limits. We have to work out a society sufficiently stable and rigid the support the human being and allow him to function out of its rigidity but at the same time sufficiently elastic to permit him to go beyond its bounds. For it is only by transcending the limits of the culture at any given moment that an advance can be made. (Huxley, 1961, pp. 61-2) 


\section{BIBLIOGRAPHY}

Aranda, Robert G. "The Mexican-American Syndrome", American Journal of Public Health, Vol. 61, No. 1, January, 1971, pp. 104-109.

Barrio, Raymond. The Plum Plum Pickers. Harper and Row, Publishers, Inc., 1971.

Birch, Herbert G. and Gussow, Joan Dye. Disadvantaged Children: Health, Nutrition and School Failure. Harcourt, Brace and World, Inc., New York, 1970.

Clark, Margaret. Health in the Mexican-American Culture. University of California Press, Berkeley, 1959.

Collins, Alice. "Natural Delivery Systems: Accessible Sources of Power for Mental Health." Draft read at the 1972 Annual Program Meeting of the American Orthopsychiatry Association.

Currier, Richard. "The Hot-Cold Syndrome and Symbolic Balance in Mexican and Spanish-American Folk Medicine": Ethnology, Vol. V, July 1966, \#3, pp. 251-263.

Galarza, Ernesto; Gallegos, Herman; and Samora, Julian. Mexican-Americans in the Southwest. McNally and Loftin, Publishers, Santa Barbara, 1970.

Gallegos, foseph s. "Developments in Chicano Curriculum", Portland State University, School of Social Work, 1972-1973. (Practicum)

Grebler, Leo; Moore, Joan; and Guzmán, Ralph. "The Family: Variations in Time and Space." Introduction to Chicano Studies. Edited by Livie Isauro Duran and H. Russell Bernard, The Macmillan Company, New York, 1973.

Johnson, Henry. "Mental Health Needs of Mexican-Americans". Presented to the Regional Training Program to Serve Bi-lingual/Bicultural Exceptional Child, February, 1972.

Kay, Margarita Artschwager. "Health and IIIness in the Barrio: Women's Point of View." Reprinted from Dissertation Abstracts International, Vol. XXXIII, \#3, 1972 . 
Kiev, Ari. Ed. Magic, Faith and Healing: Studies in Primitive Tsychiatry Today, The Free Press of Glencoe, Collier-Macmillan Iimited, Iondon, 1964.

Kiev, Ari. Curanderismo: Mexican-American Folk Psychiatry. The Free Press, New York, 1968.

Madsen, William. Mexican-Americans of South Texas. Holt, Rinehart and Winston, San Francisco, 1964.

Moore, Joan W. with Cuellar, Alfredo. Mexican-Americans. Prentice-Hall, Inc., Englewood Cliffs, New Jersey, 1971.

Murillo, Nathan. "The Mexican-American Family", in Chicanos: Social and Psychological Perspectives. Edited by Nathaniel Wagner and Marsha Haug, the C.V. Mosby Company, st. Louis, 1971, pp. 97-108.

Ortego, Philip D. We Are Chicanos: An Anthology of MexicanAmerican Literature. Washington Square Press, New York, 1973 .

Paz, Octavio. The Labyrinth of Solitude: Life and Thought in Mexico. Grove Press, Inc., New York, 1961.

Romano, Octavio Ignacio. Ed. El Espejo (The Mirror): Selected Mexican-American literature. Quinto Sol Publications, Inc., 1971.

Rubel, Arthur. Across the Tracks: Mexican-Americans in a Texas City. University of Texas Press, Austin, 1966.

Rubel, Arthur. "Concepts of Disease in Mexican-American Culture." American Anthropologist. Vol. 62 (1966), pp. 795-814.

Rusca, Alberto. El Libro de Los Remedios. Mexico, D.F. 1940.

Samora, Julian. Ed. La Raza: Forgotten Americans. University of Notre Dame Press, Notre Dame, Iondon, 1966.

Sanchez, Armand. "The Definers and the Defined: A Mental Health Issue". El Grito, Vol. IV, \#4, Summer 1971.

Saunders, Iyle. Cultural Difference and Medical Care. Russell Sage Foundation, New York, 1954.

Saunders, Iyle; and Samora, Julian. "A Medical Care Program in a Colorado County" "Health, Culture and Community. Edited by Benjamin D. Paul, Russell Sage Foundation, New York, 1955. 
Saunders, Iyle. "Healing Ways in the Spanish Southwest", Patients, Physicians and Illness. Edited by E. Gartly Jaco, The Free Press, Illinois, 1958.

U. S. Department of Health, Education and Welfare. Report of the Southwest States Chicano Consumer Conference on Health. San Antonio, Texas, January 26-29, 1972. 


\section{APPENDIX}

The following was the questionnaire (both English and Spanish) distributed to the Chicana students at the Chicano college. At the time of distribution, a seperate page was allowed for responding to each story.

Thank you for agreeing to participate in this social Research Project.

Please answer the following questions and then go on to read the stories on the next pages and answer the questions following the stories;

1. Name:

(if you do not wish to sign please put a number, any number, that only you will know)

2. Where do you live?

How long have you lived there?

3. Where did you live before?

Where are you from?

4. What type of community did you come from (farm, city, town, village?

5. Age?

6. Do you speak Spanish?

7. Number in family, relatives, etc.

Hopefully this information will help in this research project and engourage better cross-cultural communication.

1. Are you willing to let this information be used in this research project? Yes_No

2. Are you willing to let us use your name?

Yes

No 
A. A young mother with a 7 month old baby boy went to visit relatives. Her uncle admired the baby like everyone did, and he didn't touch the child. The mother and ohlid retuxned to thoir hoube and later that night, the child seemed fussy, cried a lot and even got a fever. The baby wasn't any better the day after the next and so the mother took him to the doctor.

What do you think happened at the doctor's office?

What would the doctor tell the mother was wrong with her son?

would you change this story in any way?

How would you help the baby boy?

B. A mother was nursing her baby girl and someone made a loud noise behind her; she turned around very quickly and the nipple was pulled from the baby girl's mouth. Later in the day it seemed that the little girl had trouble sucking, had diarrehea, cried a lot, and had a high temperature. Her mother couldn't be sure but she thought her head looked bumpy. Since the symptoms continued, she took her girl to the doctor the next morning.

What do you think happened at the doctor's office?

What do you think the doctor would tell the mother was wrong with her little girl?

How would you help the child?

would you change this story in any way? 
C. A child of three seemed to have an upset stomach because he complained of it hurting a lot. He also had diarrhea. This trouble continued for 3 days and then the mothar took him to the dootor because he wasn't eating well and his stomach seemed upset.

What do you think happened at the doctor's office?

What do you guess the doctor told the mother was wrong with her little boy?

Would you change this story in any way?

What do you think would help the child get better?

D. A woman was walking to the store one day and saw an accident happen just 2 blocks from her. One person was seriously hurt and taken to the hospital; two others got bumps and small cuts. She went on to the store finally and when she returned she sort of thought she was pretty tired. She did her usual work around the house, greeted her children and husband and went to bed early. The next day she felt restless and didn't know why, and she was still very tired; she also didn't feel like eating. very much and her husband noticed and asked if anything was wrong. She didn't think anything was wrong but, couldn't understand why she was so tired and restless and didn't feel like eating. After three more days of this her next door neighbor who was her comadre convinced her to go the the doctor.

What do you think happened at the doctor's office?

What do you think the doctor told her was wrong with her?

How would you help this woman get back to her normal state?

Would you change this story in any way? 
Le damos las gracias por estar de acuerdo en participar en este "Social Research Project".

Favor de contestar las siguientes preguntas $y$ despues sigua leyendo las historias en las paginas siguientes y conteste las preguntes que siguen de las historias;

1. Nombre:

(si usted no gusta firmar su nombre, favor de escribir un numero, cualquier numero, ese no mas usted lo sabra.)

2. Donde vive usted?

Que tante tiempo ha vivido alli?

3. Donde vivia usted antes?

De donde es usted?

4. Que clase de comunidad vino usted? (rancho, cuidad, pueblo)

5. Edad?

6. Numero de familia, parientes, etc.

Esperamos que esta imformacion nos ayude en este projecto a tener una major comunicasion cultural.

1. Esta usted dispuesto que esta informasion sea usado en este projecto?

Si

No

2. Esta usted dispuesto que su nombre sea usado?

Si

No 
A. Una Madre muy joven con un nino de siete mesesfue a visitar sus parientes. Su tio admiraba mucho al nino, igualmente que todos los demas, pero munca acaricio al nino. La madre $y$ el nino regresaron a su hogar. Durante la noche el nino se porto muy necio, y no dejaba de llorar hasta el punto que le dio fiebre. El nino no mejoraba nada el siguiente dia. Ia madre dicidio llevarlo con el medico.

A. Que cree usted que paso en la oficina del doctor?

B. Que le diria el medico a la madre acerca de la enfermedad del nino?

C. Cambiaria usted esta historia de alguna manera?

D. Como ayudaria usted a este nino?

B. Una madre estaba dandole el pecho a su nina de pronto alguien hizo un ruido y ella voltio de repente surprendida por el ruido, quitandole el pecho a su nina. Despues durante el dia la nina parecia que tenia dificultad, al tratar de comer del pecho de su madre. Tenia simtomas de diarrea y alloraba mucho y tenia temperatura muy alta, Su mama no estaba segura, pero le parecia que estaba con ronchas en la cabeza de su ninita. Como los simtomas continuaron ella llevo a su nina con el doctor a la manana siguente.

A. Que cree usted que paso en la oficina del medico?

B. Que piensa usted que el medico le dijo a la madre que tenia la nina?

C. Cambiaria usted esta historia de sigun modo?

D. Que cree usted que ayudaria al nino mejorarse? 
C. Un nino de tres anos de eçad se quejaba de un dolor de estomago. El dolor de estomago era companado de diarrea. Estos simtomas continuaron por tres dias y la madre decidio llevario con el medico porque el nino perdio el apetito $y$ su estomago se sentia muy adisgusto.
A. Que cree usted que paso en la oficina del medico?
B. Que piensa usted que el medico le dijo a la madre que tenia el nino?
C. Cambiaria usted esta historia de algun modo?
D. Que cree usted que ayudaria al nino mejorarse?

D. Una mujer iba caminando para la tienda un dia y vio un accidente nomas 2 cuadras de donde ella estaba. Una de las personas en el accidente fue seriamente herido $y$ fue llevado al hospital; dos personas mas que ivan con el recibieron golpes minimos. La mujer siguio caminando para la tienda y finalmente cuando volvio a su hogar ella se sentia muy abatida. Ella izo su limpieza de hogar y tendio su familia, y se durmio temprano. El dia sugerte se sentia muy nerviosa y no sabia porque. Todavia se sentia muy cansada $y$ sin apitito. Su esposo la observe y le pregunto que si algo le pasaba. Ella penso que no era algo serio pere no podia comprender porque lo cansado, lo nervioso $y$ el apetito no la dejaban. Despues de tres dias su vecina que era tambien comadre, la convincio que fuera a ver el medico.

A. Que cree usted que paso en la oficina del medico?

B. Que piensa usted que le medico le dijo lo qu tenia?

C. Como ayudaria usted a esta mujer volver a su estad normal?

D. Cambiaria usted esta historia de algun modo? 